\title{
The Impact of School Feeding Programmes in Reducing Iron Deficiency Anaemia among Primary School Children in Developing Countries: A Systematic Review and Meta-Analysis of Randomized Controlled Trials
}

\author{
Mustapha Titi Yussif1,*, Lenin Vong ${ }^{2}$, and Karen Pilkington ${ }^{3}$ \\ ${ }^{1}$ Ministry of Health, Midwifery Training College-Tumu, UWR, Affiliated to the Faculty of Allied Health Sciences, Kwame Nkrumah University of Science \\ and Technology, Ghana \\ ${ }^{2}$ World Vision International-Cambodia, Cambodia \\ ${ }^{3}$ University of Portsmouth, School of Health Sciences and Social Work, UK
}

*Corresponding author: Mustapha Titi Yussif, Ministry of Health, Midwifery Training College-Tumu, UWR, Affiliated to the Faculty of Allied Health Sciences, Kwame Nkrumah University of Science and Technology, Kumasi, Ghana, E-mail: rastiti2009@hotmail.com

Received: 30 Sep, 2019 | Accepted: 15 Dec, 2019 | Published: 31 Dec, 2019

Citation: Yussif MT, Vong L, Pilkington K (2019) The Impact of School Feeding Programmes in Reducing Iron Deficiency Anaemia among Primary School Children in Developing Countries: A Systematic Review and Meta-Analysis of Randomized Controlled Trials. Nutr Food Technol Open Access 6(1): dx.doi.org/10.16966/2470-6086.165

Copyright: (c) 2019 Yussif MT, et al. This is an open-access article distributed under the terms of the Creative Commons Attribution License, which permits unrestricted use, distribution, and reproduction in any medium, provided the original author and source are credited.

Abstract

Context: Children in developing countries may survive the critical stage of the first 1000 days of life but may still carry unresolved micronutrient deficiencies into school age. Iron deficiency anaemia is the commonest form of micronutrient deficiency which affects school age children. School feeding programmes may provide an opportunity to reduce the micronutrient deficiencies in the light of limited nutrition interventions that target school age children in developing countries.

Objective: The objective of this systematic review is to examine the evidence on the impact of school feeding programmes in reducing iron deficiency anaemia among primary school children in developing countries.

Data sources: Electronic searches were carried out in PUBMED, Web of Science and Cochrane library. The reference lists of relevant articles were also hand searched.

Data extraction: Articles that were published by May 2019 where the study intervention was in-school feeding to primary school children were included.

Data analysis: A meta-analysis was conducted to evaluate changes in haemoglobin, serum ferritin and dietary iron intake following school feeding interventions. A random effects model was applied to calculate the mean differences for the net changes in the study outcomes which were all evaluated as continuous variables. Sub group analysis was conducted to explore the effects of covariates such as fortification status of meals, type of meals on the net pooled effect.

Conclusion: School feeding programmes improved dietary iron intake of primary school children, improved haemoglobin and serum ferritin concentrations and thus have a potential to reduce iron deficiency anaemia.

Keywords: Iron deficiency; Anaemia; School feeding programme

\section{Introduction}

\section{Rationale}

In spite of the significant progress in the fight against hunger and malnutrition, the prevalence of malnutrition in the general population still remains unacceptably high with about 795 million people in the world being undernourished [1].

Children are not left out of the scourge of malnutrition as 161 million children are stunted; "below minus two standard deviations from median height for age of reference population" and 51 million are wasted, "below minus two standard deviations from median weight for height of reference population" [2].
Developing countries are worse hit with under nutrition since $80 \%$ of the world's malnourished children live in just 20 developing countries in Africa, Western Pacific, Middle East and Asia [3].

Most nutrition interventions are currently focused on the first 1000 days of a child's life [4].

This is because the period provides a critical opportunity in which interventions to improve maternal and child undernutrition can have a positive impact on the prospects of survival, growth and development among young children especially in countries with a high burden of under nutrition [5].

As such pregnant women and children under the age of 2 years 
are prioritized making children of school going age less targeted with nutrition interventions making them potentially at risk of malnutrition.

School Feeding Programmes thus offer and excellent window of opportunity to target children of school going age to reduce their vulnerability to malnutrition especially in developing countries. There are as many types of school feeding programmes as there are countries however the World Food Programme defines school feeding as the provision of food to school children either as in-school feeding, where children are fed in school or take-home rations, where families are given food if their children attend school. In-school feeding is the most commonly adopted form of school feeding and entails programmes that provide both meals and high-energy biscuits or snacks [6].

Over 70 developing countries use school feeding programmes to provide meals to over 385 million school children mostly to serve as an incentive to improve school enrolment and attendance as well as reduce short term hunger and improve the nutritional status of school children [6].

School feeding programmes have proved to be effective in increasing school enrolment and retention, reducing short term hunger [7] and improving cognitive function $[8,9]$. However, evidence on the impact of school feeding programmes in improving nutritional status has been mixed and inconclusive [10].

Systematic reviews on the impact of school feeding programmes on nutritional status have often focused on physical nutrition outcomes such as children's anthropometry [11,12] with little attention on micronutrient status.

Children of school going age are not only prone to protein energy malnutrition but also to micronutrient malnutrition which is a "hidden" form of undernutrition. Micronutrient malnutrition can adversely affect child growth and development, increase susceptibility to frequent infections and has implications for child survival [13].

Iron deficiency is one of the commonest forms of micronutrient deficiency which affects 305 million (25.4\%) school age children globally and $40 \%$ in developing countries [14] making it a serious public health problem [15].

Iron is an important component of haemoglobin and myoglobin which are both proteins and required for the transport of oxygen, and it also plays important roles in immune functions and energy production [16].

The main source of iron in the body is through dietary intake either from animal sources as haeme iron or from largely plant sources as non-haeme iron [17]. The level of iron in the body is maintained by the regulation of iron absorption in the small intestine in the absence of losses through active excretion [17].

Iron deficiency results from low dietary iron intake and/or from poor bioavailability of dietary iron to the extent that the body cannot up regulate iron to meet its needs [18]. It is the most significant contributing factor to anaemia, low blood haemoglobin concentration [19]. Approximately $50 \%$ of the global cases of anaemia are considered to be due to iron deficiency though the proportion probably varies among population groups and in different areas, according to the local conditions [20].

Anaemia occurs at all stages of the life cycle, but prevalence levels are higher among pregnant women and young children [14]. Young children from low income families have a higher risk of developing anaemia due to iron deficiency that occurs as a result of high demand for iron during the period of rapid growth which tends not to be met by dietary intakes at the household level [21]. In addition, there is a further increase in iron requirements in older school girls due to the onset of menstruation [22].

Anaemia is known to have deleterious effects such as impaired cognitive performance, behavior and physical growth among young children [23].

\section{Objectives}

This systematic review which was done following Preferred Reporting Items for Systematic Reviews and Meta-Analyses (PRISMA) guidelines aims to evaluate the impact of school feeding programmes in reducing iron deficiency anaemia among primary school children in developing countries. The authors specifically assessed how school feeding programmes impact on haemoglobin and serum ferritin concentrations of primary school children and examined the contribution of school feeding programmes to dietary iron intake of primary school pupils.

\section{Methods}

\section{Eligibility criteria}

Type of studies: In order to synthesize evidence of the highest standard, Randomized Trials which are deemed the gold standard of primary research [24] were included in this review and used for both qualitative and quantitative synthesis (meta-analysis). Conference abstracts of randomized trials that did not have sufficient information however were excluded from this review.

Observational studies including prospective cohort and cross sectional studies have also been included in the review and used only for the purpose of qualitative synthesis (systematic review) and hence did not contribute to the pooled effect estimates which constitute the main conclusions of this review. No language and publication date restrictions were imposed.

Type of participants: Studies whose subjects were primary school children from developing countries were included in this review. Studies where the participants were described as primary school children were included hence no specific age restrictions were applied to determine inclusion of study participants because of variations in age cut offs for primary school. Developing countries were determined using the World Bank's list of economies [25] and inclusion was not restricted based on geographical differences in socio economic status within developing countries.

Type of intervention: Studies were only included in this review if the main treatment element/intervention was a school feeding programme. School feeding programmes are interventions where meals are provided to school children either as take-home rations or in-school meals [6].

In this review school feeding was limited in definition to in-school meals including breakfast or lunch provided at school level and also snacks but excluded take-home food rations. Take-home food rations were excluded because food may be shared with other members of the family [26] and effect measures may be misleading.

Studies that had multiple-arm interventions were included in this review and the results of the intervention that fits the definition of school feeding described above were included in the quantitative synthesis.

Studies were excluded if they evaluated food stamps and school based micronutrient supplementation. 
Type of outcome measures: The primary outcome of this review is iron deficiency anaemia status hence the inclusion criteria for the studies used in this review covered studies that measured indicators of iron deficiency anaemia status (haemoglobin levels and serum ferritin concentrations) of both the intervention/experimental and control groups.

Studies that evaluated the effects of school feeding programmes on dietary iron intakes of primary school pupils were also included in this review as a secondary outcome of interest. The Participants, Interventions, Comparators, Outcomes and Study design (PICOS) criteria for inclusion and exclusion are described in table 1.

\section{Information sources}

The studies included in this review were mainly published peer reviewed articles identified using electronic database searches from the COCHRANE LIBRARY, PUBMED and WEB OF SCIENCE.

Additionally, World Health Organization (WHO) international clinical trials registry platform (http://apps.who.int/trialsearch/) was also searched for studies which have been completed but not published in peer review journals as a way of exploring grey literature and to reduce publication bias.

Reference lists of articles that were included based on the electronic database searches were also hand searched and used for the review.

\section{Search}

A number of different search terms were used to identify the studies that were used in this review. The basic search terms that was used included, 'school lunch', 'school feeding', 'mid-day meal', 'school meals', 'school nutrition'. Some additional terms that were used included 'anaemia', 'iron deficiency' and 'nutritional status'. The search was done using a combination of the basic and additional terms to generate the articles (Table 2).

\section{Selection of studies and data synthesis}

The search of electronic databases: Cochrane library, Web of Science and PUBMED generated a total of 774 articles, 2 articles were obtained from references and 5 additional articles were obtained as grey literature. 774 articles remained after duplicates were removed.
Through the screening of titles and abstracts, 746 articles were excluded leaving 28 articles upon which full text reading was done. Checking for eligibility using the inclusion and exclusion criteria, 16 articles were included in the review of which 10 articles were randomized trials and 6 studies were observational studies (Figure 1).

\section{Data collection process}

Data collection forms were developed a priori in a way that allowed eligibility to be assessed and that extracted data responded to the research questions. The data extraction forms were pilot- tested using three included articles to ensure that they were easy to use and that data extracted was consistent, clear and complete. Eligibility assessment was done by two persons independently and disagreements resolved by consensus.

Data was extracted on study characteristics such as year, country of origin, study design, sample sizes for intervention and control groups, gender, age and length of intervention. Description of the intervention and outcome measurement as well as key findings and data on direction of results were also extracted. Data was also collected on potential effect modifiers and recorded in a remark column.

Authors of three studies [27-29] were contacted via email to request unreported data such as group means and standard deviations of haemoglobin and serum ferritin concentrations of study participants at both baseline and end line to facilitate the calculation of the effect size of the interventions and also to evaluate attrition. However, a response was received from only one author [27].

\section{Risk of bias assessment in individual studies}

Methodological quality appraisal of Randomized Controlled Trials (RCTs) was done using risk of bias assessment based on the Cochrane risk of bias tool in the following areas; random sequence generation, allocation concealment, blinding of participants and personnel, blinding of outcome assessment, incomplete outcome data (>20\% loss), selective reporting and other bias [30].

Each study was assessed and judged to be of low risk of bias (adequate) or of high risk of bias (inadequate) or unclear risk of bias (unclear) for each of the areas of risk of bias tool. Risk of bias data was entered into RevMan software (version 5.3, Cochrane Collaboration) to produce summary tables and graphs. (Table 2)

Table 1: PICOS Criteria for Inclusion and Exclusion of Studies.

\begin{tabular}{|c|c|c|}
\hline PICOS Criteria & Inclusion & Exclusion \\
\hline \multirow{2}{*}{ Participants } & Study subjects being primary school children & Pre-school children and high school children \\
\hline & Study participants being from a developing country & Study participants being from a developed country \\
\hline \multirow{3}{*}{ Interventions } & \multirow{3}{*}{$\begin{array}{l}\text { School feeding in-school meals provided; breakfast or lunch or } \\
\text { snacks }\end{array}$} & Take home food rations \\
\hline & & School based micronutrient supplementation \\
\hline & & Food stamps \\
\hline \multirow{2}{*}{ Comparators } & Articles with an intervention and comparison group/control group & \multirow{2}{*}{$\begin{array}{l}\text { Control group receiving any form of in-school feeding/ } \\
\text { micronutrient supplementation }\end{array}$} \\
\hline & Control/comparison group did receive any kind of & \\
\hline \multirow[t]{2}{*}{ Outcomes } & $\begin{array}{l}\text { Primary: studies that measured indicators of iron deficiency } \\
\text { anaemia (haemoglobin and serum ferritin concentrations) }\end{array}$ & \\
\hline & Secondary: dietary iron consumption from in-school meals & \\
\hline \multirow{2}{*}{ Study Design } & Randomized trials & \multirow{2}{*}{$\begin{array}{l}\text { Conference abstracts of randomized trials without sufficient } \\
\text { information }\end{array}$} \\
\hline & Observational studies; to be used for only qualitative synthesis & \\
\hline
\end{tabular}

Citation: Yussif MT, Vong L, Pilkington K (2019) The Impact of School Feeding Programmes in Reducing Iron Deficiency Anaemia among Primary School Children in Developing Countries: A Systematic Review and Meta-Analysis of Randomized Controlled Trials. 


\section{Summary measures and synthesis of results}

Meta-analysis was conducted on studies reporting similar comparisons for the same outcome measures using RevMan (version 5.3, Cochrane Collaboration) and adopting a random effects model which was determined a priori because the studies had eminent clinical heterogeneity. All the three outcomes of this review, haemoglobin and serum ferritin concentrations as well as dietary iron intakes were evaluated as continuous outcomes using mean differences. In studies where haemoglobin and ferritin concentrations were measured in metrics other than $\mathrm{g} / \mathrm{dl}$ and $\mu \mathrm{g} / \mathrm{l}$ respectively, they were converted and used in the meta-analysis.

For studies that presented outcome data as medians with upper and lower quartiles instead of mean and standard deviation, a normal distribution was assumed and the median was used in the analysis while standard deviations were calculated by dividing the inter quartile range by 1.35 [31].

\section{Risk of bias across studies}

Both clinical and statistical heterogeneity were assessed. The type of intervention, study participants and outcomes were considered in the assessment of clinical heterogeneity whilst visual inspection of forest plots, $\mathrm{I}^{2}$ measure for heterogeneity [32] and chi square test were used to assess statistical heterogeneity. An $\mathrm{I}^{2}$ greater than $75 \%$ was evaluated as considerable heterogeneity [32].

The studies used for the meta-analysis were few hence it was inappropriate to use funnel plots to assess publication bias [33]. However, a robust search strategy was adopted and included an extensive hand search of references and the use of the WHO and WFP websites to identify articles that were not published in peer reviewed journals as a means of avoiding publication bias.

\section{Additional analysis}

Subgroup analysis was planned by age, sex, socioeconomic status, and fortification status of meals, types of meals (snack/lunch), anaemia status of participants and location of feeding. However, the included studies did not stratify the results for the outcomes of interest by age, sex and socio economic status hence subgroup analysis was not possible for these categories. (Table 3)

Sub group analysis was performed by fortification status of meals for haemoglobin concentration, serum ferritin concentration as well as dietary iron intake as all these outcomes could be influenced by whether the meals used for the intervention are fortified with iron or not [34].

The type of meals provided during the intervention (whether snack or lunch made from local recipes) was investigated as a potential source of heterogeneity in all three outcomes of interest in this review. Because of the differences in available iron from animal and plant based diets [35] an additional sub group analysis by type of meals in terms of whether the meals are made of animal sources or non-animal sources was performed for dietary iron intake.

It was hypothesized that school feeding would be more effective in improving haemoglobin and serum ferritin levels of children who are anaemic before the intervention hence a sub group analysis was conducted based on anaemia status of participants enrolled in the trials.

The location where the intervention trials was conducted was also explored as a potential source of heterogeneity due to differences in types of food available, dietary behaviors and other factors which can affect dietary iron intake and absorption. A subgroup analysis was therefore conducted by continent/sub region for all three outcomes; haemoglobin, serum ferritin levels and dietary iron intake.

\section{Results \\ Study selection}

The search of electronic databases: Cochrane library, Web of Science and PUBMED was conducted in May 2018 and updated in June 2019. The search generated a total of 774 articles, 2 articles were obtained from references and 5 additional articles were obtained through other sources. Upon checking for eligibility using the inclusion and exclusion criteria, 16 articles were included in the review of which 10 articles were controlled trials and 6 studies were observational studies. See results of search as shown in study flow diagram in figure 1.

\section{Characteristics of included studies}

The review included studies representing a wide variety of countries. Studies were from eleven (11) developing countries across three (3) continents. Majority of the studies were conducted in Africa ( 6 countries); [23,28,29,36-41] followed by Asia (4 countries) [42-46] and Latin America (3 countries) [27,47,48].

All the participants in the studies that were used in the review were primary school pupil with age range between 4 and 15 years. See table of included studies (Apendix 6 and 7) for details of participants in each study. The number of participants per study ranged from 147 [39] to 1,116 [27] with a total of 2,551 participants included in the trials that were analyzed for the impact of school feeding programmes on haemoglobin. 1,627 and 1,187 participants included in trials were used to evaluate programme impact on serum ferritin and dietary iron intake respectively. (Table 4)

All the trials included in this review provided the feeding intervention in a school setting with or without added micronutrients. The length of the interventions ranged from 3 months $[27,40]$ to 24 months [27] with an average of 9 months of feeding. The type of feeding provided varied from snacks (Milk, beverages, biscuits) to lunch meals made from local foods.

\section{Risk of bias in included studies}

For the randomized control trials which have been included in this review, the risk of bias judgements have been shown in the 'risk of bias' summary tables and 'risk of bias' graph in figure 2 and 3 respectively.

Random sequence generation for allocation of participants was described well in two trials $[38,42]$ and were judged to have a low risk of bias while eight (8) other trials $[27,29,39,40,41,43,44,47]$ were judged to have an unclear risk of bias for random sequence generation because the method of sequence generation was not reported.

Aaron GJ, et al. [38] was judged to be of low risk of bias for allocation concealment whiles Muthayya S, et al. [42] was rated as having a high risk of bias for allocation concealment because the allocation was done by date of birth. The remaining nine (9) trials in this review were rated as unclear risk of bias for allocation concealment.

Blinding of participants and personnel in the feeding trials was not described in any of the studies. However all the studies were judged to be of low risk of bias for blinding of participants because the outcomes of interest are not likely to be influenced by a lack of blinding.

For blinding of outcome assessment, five (5) trials [29,38,39,42,43] were rated as having a low risk of bias. Three (3) trials $[27,40,47]$ were 
Table 2: Search strategy.

Search (((("school feeding") OR "school lunch*") OR "school meal*")) AND nutritional status[MeSH Terms]

Search ((((("school feeding") OR "school lunch*") OR "school meal*") AND Humans[Mesh])) AND anemia[MeSH Terms] AND (Humans[Mesh])

Search (((schools[MeSH Terms]) AND food services[MeSH Terms]) AND nutritional status[MeSH Terms]) OR anemia[MeSH Terms]

Search (((schools[MeSH Terms]) AND food services[MeSH Terms]) AND nutritional status[MeSH Terms]) OR micronutrients[MeSH Terms]

Search (((schools[MeSH Terms]) AND food services[MeSH Terms]) AND nutritional status[MeSH Terms]) OR anemia[MeSH Terms]

Search ((((("school feeding") OR "school lunch*") OR "school meal*") AND Humans[Mesh])) AND anemia, iron deficiency[MeSH Terms]

Search ((((("school feeding") OR "school lunch*") OR "school meal*") AND Iron deficiency[Mesh])) AND anemia[MeSH Terms]

("school feeding") AND iron intake AND (full text[sb] AND Humans[Mesh])

Search ((((("school feeding"[ti]) OR "school meal*"[ti]) OR "school lunch*"[ti]) AND free full text[sb])) AND health AND (free full text[sb]) Schema: syn
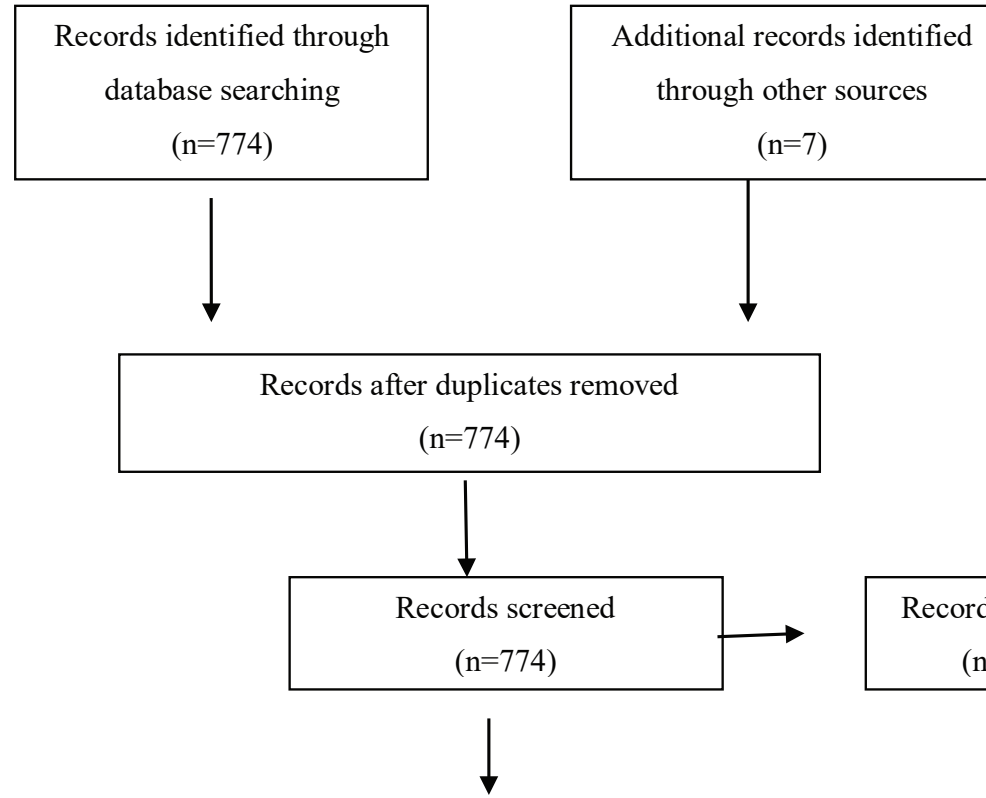
Records excluded
$(n=746)$

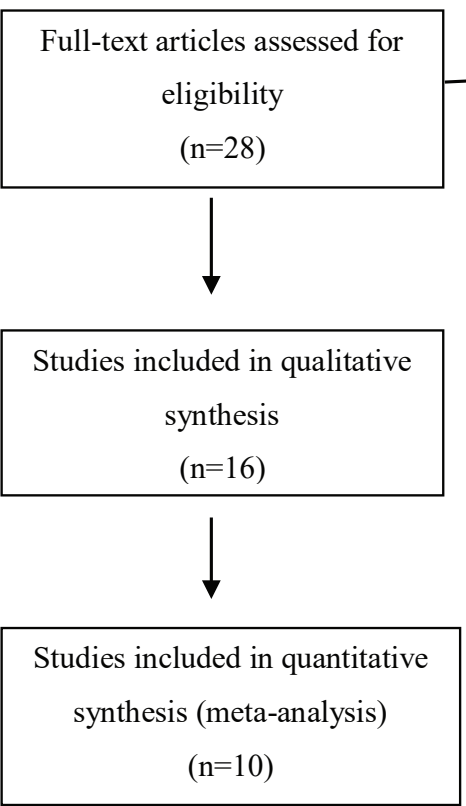

Full-text articles

excluded, with

reasons

$(\mathrm{n}=12)$

Excluded based on;

Inappropriate control

Iron supplementation

provided (2)

Figure 1: Flow Diagram of Literature Search Process. 
Table 3: Effect estimates on outcomes stratified by fortification status of meals.

\begin{tabular}{|c|c|c|c|c|}
\hline Outcome or Subgroup & Studies & Participants & Statistical Method & Effect Estimate \\
\hline 1.1 Haemoglobin Level & 8 & 2551 & Mean Difference (IV, Random, 95\% CI) & $0.22[0.01,0.43]$ \\
\hline 1.1.1 Fortified meals & 6 & 1870 & Mean Difference (IV, Random, 95\% CI) & $0.33[0.11,0.55]$ \\
\hline 1.1.2 Unfortified meals & 2 & 681 & Mean Difference (IV, Random, 95\% CI) & $-0.06[-0.30,0.17]$ \\
\hline 1.2 Serum Ferritin Level & 6 & 1627 & Mean Difference (IV, Random, 95\% CI) & $7.43[0.02,14.84]$ \\
\hline 1.2.1 Fortified meals & 5 & 1404 & Mean Difference (IV, Random, 95\% CI) & $5.74[-2.18,13.67]$ \\
\hline 1.2.2 Unfortified meals & 1 & 223 & Mean Difference (IV, Random, 95\% Cl) & $20.00[5.30,34.70]$ \\
\hline 1.3 Iron intake & 9 & 1187 & Mean Difference (IV, Random, 95\% CI) & $1.88[0.95,2.81]$ \\
\hline 1.3.1 Fortifiied meals & 1 & 106 & Mean Difference (IV, Random, 95\% Cl) & $5.10[4.21,5.99]$ \\
\hline 1.3.2 Unfortified meals & 8 & 1081 & Mean Difference (IV, Random, 95\% Cl) & $1.12[0.41,1.84]$ \\
\hline
\end{tabular}

Table 4: Effect estimate on outcomes stratified by type of feeding.

\begin{tabular}{|c|c|c|c|c|}
\hline Outcome or Subgroup & Studies & Participants & Statistical Method & Effect Estimate \\
\hline 3.1 Hemoglobin concentrations & 8 & 2551 & Mean Difference (IV, Random, 95\% CI) & $0.22[0.01,0.43]$ \\
\hline 3.1.1 Snack Group & 6 & 1991 & Mean Difference (IV, Random, 95\% CI) & $0.17[-0.05,0.38]$ \\
\hline 3.1.2 Lunch Group & 2 & 560 & Mean Difference (IV, Random, 95\% CI) & $0.53[0.20,0.87]$ \\
\hline 3.2 Serum Ferritin concentration & 6 & 1627 & Mean Difference (IV, Random, 95\% CI) & $7.43[0.02,14.84]$ \\
\hline 3.2.1 Snack Group & 4 & 1106 & Mean Difference (IV, Random, 95\% CI) & $8.12[-3.64,19.89]$ \\
\hline 3.2.2 Lunch Group & 2 & 521 & Mean Difference (IV, Random, 95\% CI) & $7.80[-1.74,17.33]$ \\
\hline 3.3 Iron Intake & 9 & 1187 & Mean Difference (IV, Random, 95\% CI) & $1.88[0.95,2.81]$ \\
\hline 3.3.1 Snack Group & 3 & 333 & Mean Difference (IV, Random, 95\% CI) & $4.70[0.30,9.11]$ \\
\hline 3.3.2 Lunch Group & 6 & 854 & Mean Difference (IV, Random, 95\% CI) & $0.31[-0.17,0.79]$ \\
\hline
\end{tabular}

rated as have a high risk of bias because outcome (dietary iron intake) assessment was done through $24 \mathrm{hr}$ recalls and as such lack of blinding could result in detection bias Hulett JL, et al. [41] and do Lien TK, et al. [44] did not report on blinding of outcome assessment and were thus judged to have an unclear risk of bias for blinding.

Nine (9) of the trials included in this review [27,29,39,40,41,43,44,47] were judged to have a low risk of attrition bias. Aaron GJ, et al. [38] and Muthayya S, et al. [42] were rated as having high risk of bias and unclear risk of bias respectively for incomplete outcome data.

Low risk of reporting bias was noted in five (5) studies [40-44] as their protocols were available and primary and secondary outcomes were reported as indicated in their respective protocols.

Five (5) other trials $[27,29,38,39,47]$ though reported at least one of the outcomes of interest in this review, were judged to have an unclear risk of risk of reporting bias as their protocols could not be retrieved hence there was no enough information available to serve as basis of judgment.

Preference and consent bias were the other potential sources of bias that were evaluated. Four (4) trials [38,42-44] were judged to have a potential risk of preference bias because they enrolled only children who were not severely anaemic into the feeding trials. This implies that children who would have most likely benefitted more from the feeding interventions were excluded from the research.

Van Stuijvenberg ME, et al. [39], Murphy SP, et al. [40], Lannotti LL, et al. [27], Kazianga H, et al. [29], 9 were rated as having low risk of other potential sources of bias whiles two other studies [41,47] were rated with an unclear risk of other potential sources of bias.

\section{Synthesis of Results}

\section{Haemoglobin concentration}

Six randomized controlled trials [27,38,39,42-44,] with a total of 2,551 school children were included in a meta-analysis to evaluate the impact of school feeding on haemoglobin levels. Two of the randomized controlled trials $[27,44]$ provided two arm interventions which were all included in the analysis.

School feeding was conducted in these trials for an average of 6 months with either snacks in the form of biscuits and cereal based beverages $[27,29,39]$ or lunch using local foods and recipes $[42,43]$ or milk [44]. The results of the meta-analysis show a small significant impact of school feeding programmes on increasing haemoglobin levels. Haemoglobin levels of children who were fed in school increased by an average of $0.22 \mathrm{~g} / \mathrm{dl}$ ( $95 \%$ confidence interval of 0.01 to 0.43 ) compared with those who were not fed. The increase was significant at $\mathrm{p}=0.04$. See the forest plots on haemoglobin in figure 4 .

There was considerable heterogeneity in the trials that contributed to the pooled effect $\left(\mathrm{Tau}^{2}=0.07 ; \mathrm{chi}^{2}=35.05 ; \mathrm{df}=7 ; \mathrm{p}<0.0001 ; \mathrm{I}^{2}=80 \%\right)$.

Sub group analysis was conducted to explore the effects of the fortification status of food used for the intervention, the type of feeding, anaemia status of participants and location of feeding on haemoglobin concentration of the children. 


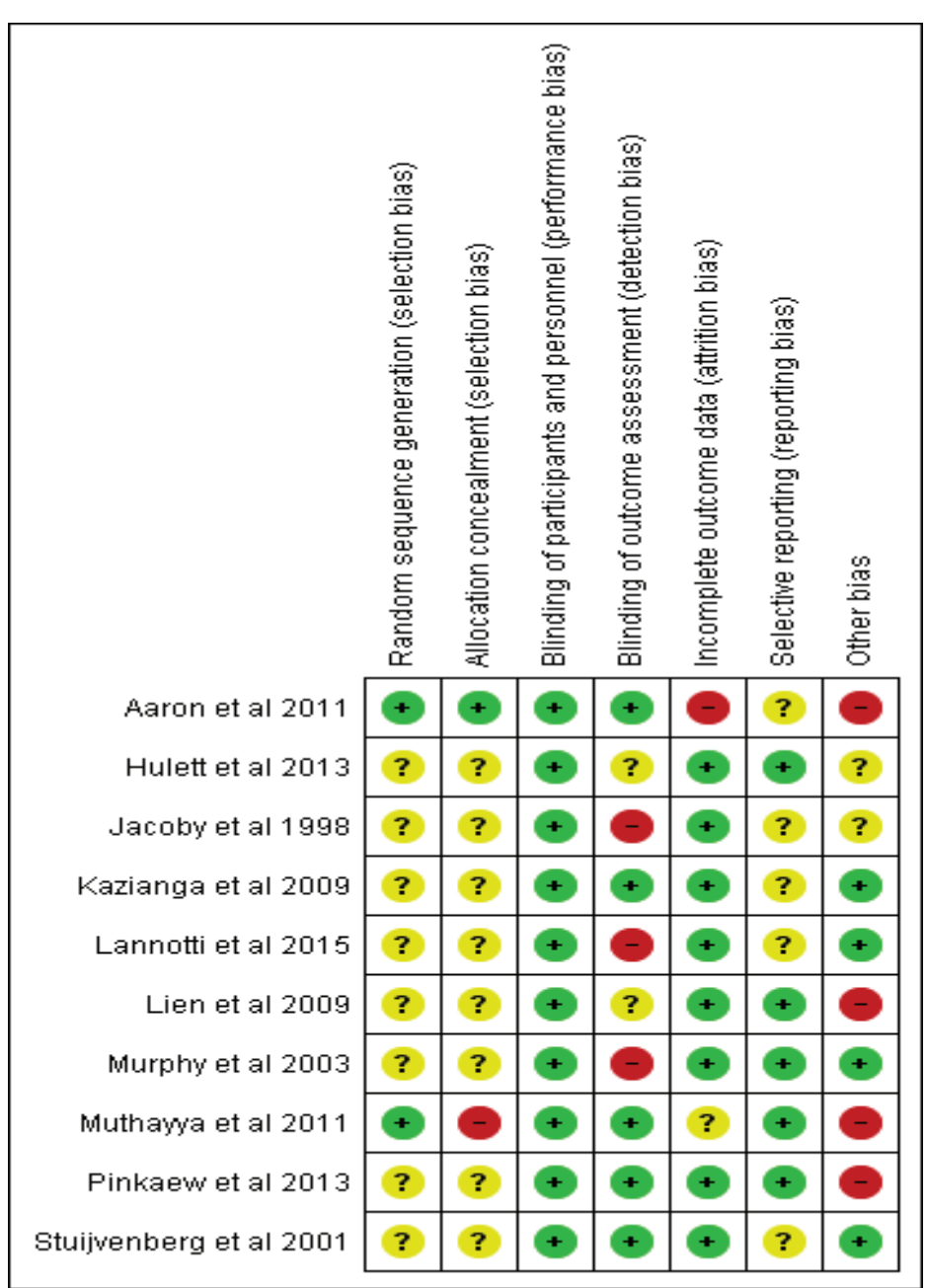

Figure 2: Risk of bias summary: review author's judgments about each risk of bias item for each included study.

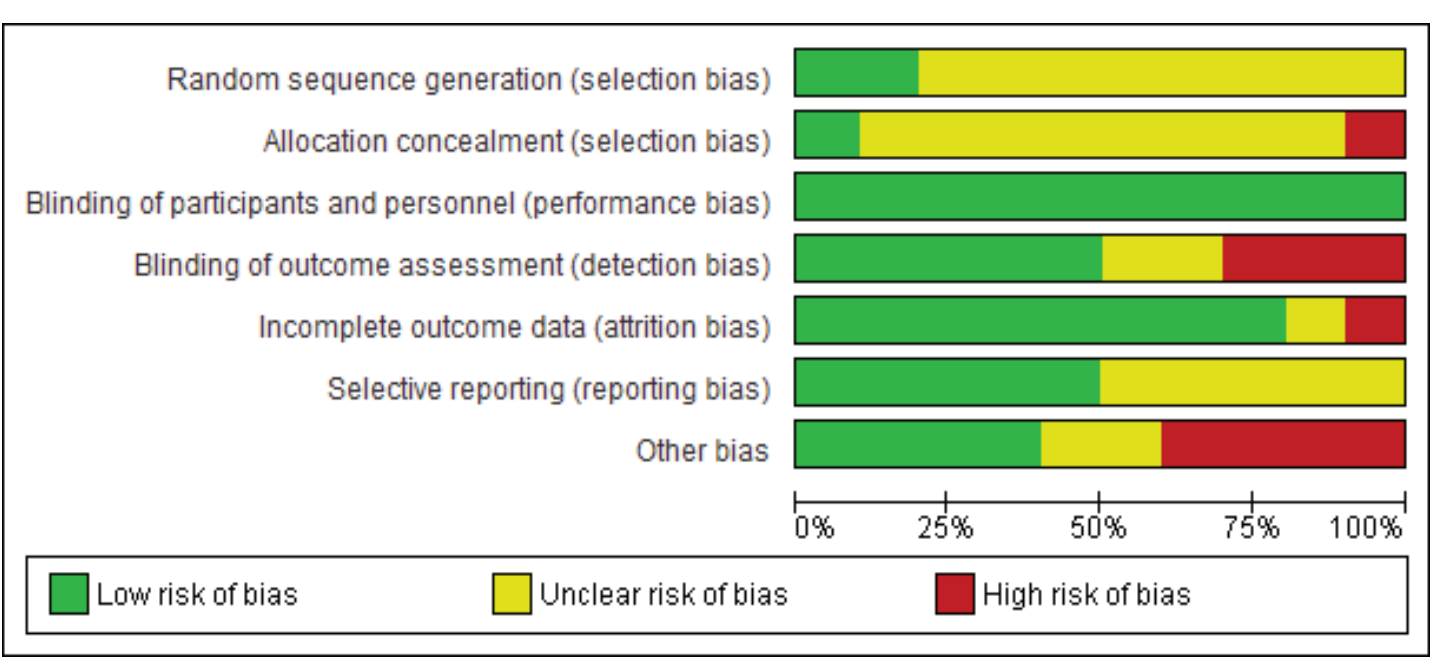

Figure 3: Risk of bias graph: review author's judgments about each risk of bias item presented as percentages across all included studies. 
This analysis found significant differences in the effect of fortification status of meals used for the intervention on haemoglobin levels ( $\mathrm{chi}^{2}=5.72, \mathrm{df}=1, \mathrm{I}^{2}=82.5 \%$ ) significant at $\mathrm{p}=0.02$. School feeding was effective in increasing the haemoglobin levels of children who received meals that were fortified with iron and other micronutrients compared to children who received unfortified meals.

Children who received fortified foods significantly increased their haemoglobin levels by $0.33 \mathrm{~g} / \mathrm{dl}$ (95\% confidence interval of 0.11 to $0.55 ; \mathrm{p}=0.03$ ) over their controls whiles those who were fed with unfortified foods rather had decreased haemoglobin concentrations compared to their controls although the reduction was not significant $(\mathrm{p}=0.60)$.

The type of meals provided during the trials whether snack or lunch prepared using local recipes contributed differently to the overall effect on haemoglobin levels $\left(\mathrm{chi}^{2}=3.24, \mathrm{I}^{2}=69.1 \% ; \mathrm{p}=0.07\right)$. In trials where a lunch was provided, the programme significantly $(\mathrm{p}=0.002)$ increased haemoglobin concentrations by $0.53 \mathrm{~g} / \mathrm{dl}$ (95\% CI; 0.20-0.87) whiles no significant impact was observed in the snack subgroup.

Four studies [36,41-43] enrolled only children who are not severely anaemic at baseline (haemoglobin concentration of $>70 \mathrm{~g} / \mathrm{l}$ ). In this subgroup, the feeding programmes have been effective in significantly increasing the haemoglobin concentration of program beneficiaries by $0.29 \mathrm{~g} / \mathrm{dl}$ over controls. In the other subgroup where children who were severely anaemic were included in the trials $[27,39]$ the effect of feeding in increasing haemoglobin levels was marginal and not significantly different from that of controls $(0.12,95 \% \mathrm{CI},-0.36-0.61, \mathrm{p}=0.62)$.

A subgroup analysis based on the location of trials show that school feeding had a significant positive impact on haemoglobin levels of children in Asia where program beneficiaries had their haemoglobin concentrations increased by $0.32 \mathrm{~g} / \mathrm{dl}$ (95\% CI, 0.05-0.59; $\mathrm{p}=0.02$ ). Results from trials conducted in Africa and Latin America showed no significant positive impact of school feeding programmes on haemoglobin levels of participating children; 0.40 (95\% CI, -0.02-0.83; $\mathrm{p}=0.06)$ and $-0.12(95 \% \mathrm{CI},-0.31-0.06 ; \mathrm{p}=0.19)$ respectively.

\section{Serum ferritin concentration}

Four (4) single arm intervention trials $[38,39,42,43]$ and one double arm intervention trial [44] were included in the meta-analysis to evaluate the impact of school feeding programmes on serum ferritin levels of primary school pupils in developing countries.

The type of feeding provided in the trials varied from biscuit snacks and cereal beverages $[38,39]$ to milk $[44]$ and lunch meals made from local recipes $[42,43]$. The average feeding period for the trials was 7 months and a total of 1,627 participants were used in the analysis.
There was a statistically significant $(\mathrm{p}=0.05)$ increase (by 7.43 $\mu \mathrm{g} / \mathrm{l} ; 95 \%$ CI $0.02-14.84$ ) in serum ferritin concentration among the children who benefited from the feeding programmes over those who were not fed in school as shown in the forest plots on serum ferritin concentration in figure 5 .

The studies were considerably heterogeneous at an $\mathrm{I}^{2}$ of $88 \%$, $\mathrm{Tau}^{2}=64.40 ; \mathrm{Chi}^{2}=41.08, \mathrm{df}=5, \mathrm{p}<0.00001$. A subgroup analysis based on fortification status of the meals used for the interventions showed no differences $\left(\mathrm{Chi}^{2}=2.80 ; \mathrm{df}=1(\mathrm{p}=0.09) ; \mathrm{I}^{2}=64.3 \%\right)$.

Children who were fed fortified meals had a slightly increased serum ferritin levels $(5.74 \mu \mathrm{g} / \mathrm{l})$ over their controls $(\mathrm{p}=0.16$; $95 \% \mathrm{CI}$; -2.18-13.67). One trial [44] which provided non fortified regular milk to school children showed a significantly higher increase in serum ferritin levels of the beneficiaries compared to the non-beneficiaries $(20 \mu \mathrm{g} / \mathrm{l} ; \mathrm{p}=0.008,95 \% \mathrm{CI} ; 5.30-34.70)$.

Trials in which a snack was provided and those in which a lunch was provided using local recipes were homogenous in their contribution to the overall effect of school feeding programmes on serum ferritin levels $\left(\mathrm{Chi}^{2}=0.00 ; \mathrm{df}=1 ; \mathrm{I} 2=0 \% ; \mathrm{p}=0.97\right)$. Both snack and lunch sub groups recorded increases in serum ferritin levels over their controls however the increases were not significant $(8.12$ $\mu \mathrm{g} / \mathrm{l} ; 95 \% \mathrm{CI} ;-3.64-19.89 ; \mathrm{p}=0.18$ and $7.8 \mu \mathrm{g} / \mathrm{l} ; 95 \% \mathrm{CI},-1.74$-17.33; $\mathrm{p}=0.11$ respectively).

The anaemia status of children enrolled in the feeding programmes also has an effect on programme impact on serum ferritin levels. In trials that enrolled children who were not severely anaemic in the feeding intervention, serum ferritin concentrations were observed to have increased significantly ( $\mathrm{p}=0.02$ ) over their controls by $9.61 \mu \mathrm{g} / \mathrm{l}$ (95\% CI; 1.78-17.44). Studies that included severely anaemic children did not have any positive impact on serum ferritin levels of children who were enrolled in the feeding programmes compared to those who were not. The results showed a rather reduced serum ferritin levels by $4.69 \mu \mathrm{g} / \mathrm{l}$ (95\% CI; -14.69-5.31; $\mathrm{p}=0.36)$.

Three (3) of the trials [42-44] that were conducted in Asia showed an overall positive effect of school feeding on serum ferritin levels of children. School feeding beneficiaries showed a significantly higher $(\mathrm{p}=0.01)$ serum ferritin concentration over their controls by $12.3 \mu \mathrm{g} / \mathrm{l}$ (95\% CI; 4.64-19.99).

The trials that were conducted in Africa [38,39] showed no overall positive school feeding programme impact on serum ferritin levels of children $(-0.69 \mu \mathrm{g} / \mathrm{l}(95 \% \mathrm{CI} ;-4.52-3.14 ; \mathrm{p}=0.72)$ whiles no trial conducted in Latin America evaluated school feeding programme impact on serum ferritin levels of school children (Tables 5-7).

Table 5: Effect estimates on outcomes stratified by anaemia status.

\begin{tabular}{|l|c|c|l|l|}
\hline \multicolumn{1}{|c|}{ Outcome or Subgroup } & Studies & Participants & \multicolumn{1}{c|}{ Statistical Method } & \multicolumn{1}{c|}{ Effect Estimate } \\
\hline 4.1 Haemoglobin level & 8 & 2551 & Mean Difference (IV, Random, 95\% Cl) & $0.22[0.01,0.43]$ \\
\hline 4.1.1 Non Severely Anaemic & 5 & 1527 & Mean Difference (IV, Random, 95\% Cl) & $0.29[0.09,0.49]$ \\
\hline 4.1.2 Severely Anaemic & 3 & 1024 & Mean Difference (IV, Random, 95\% Cl) & $0.12[-0.36,0.61]$ \\
\hline 4.2 Serum Ferritin level & 6 & 1627 & Mean Difference (IV, Random, 95\% Cl) & $7.43[0.02,14.84]$ \\
\hline 4.2.1 Non Severely Anaemic & 5 & 1488 & Mean Difference (IV, Random, 95\% Cl) & $9.61[1.78,17.44]$ \\
\hline 4.2.2 Severely Anaemic & 1 & 139 & Mean Difference (IV, Random, 95\% Cl) & $-4.69[-14.69,5.31]$ \\
\hline 4.3 Iron Intake & 9 & 1187 & Mean Difference (IV, Random, 95\% Cl) & $1.88[0.95,2.81]$ \\
\hline 4.3.1 Animal Source meals & 2 & 252 & Mean Difference (IV, Random, 95\% Cl) & $0.34[0.07,0.61]$ \\
\hline 4.3.2 Non Animal Source meals & 7 & 935 & Mean Difference (IV, Random, 95\% Cl) & $2.48[1.15,3.82]$ \\
\hline
\end{tabular}

Citation: Yussif MT, Vong L, Pilkington K (2019) The Impact of School Feeding Programmes in Reducing Iron Deficiency Anaemia among Primary School Children in Developing Countries: A Systematic Review and Meta-Analysis of Randomized Controlled Trials. 
Table 6: Summary table of included studies: controlled trials.

\begin{tabular}{|c|c|c|c|c|c|c|}
\hline $\begin{array}{l}\text { Study (year), } \\
\text { and Location }\end{array}$ & $\begin{array}{c}\text { Sample Size }(n), \text { age of } \\
\text { participants }\end{array}$ & $\begin{array}{l}\text { Duration of } \\
\text { intervention }\end{array}$ & $\begin{array}{c}\text { Measurement of exposure and } \\
\text { outcomes of interest }\end{array}$ & Summary of key findings & $\begin{array}{l}\text { Direction of } \\
\text { results }\end{array}$ & Remarks \\
\hline $\begin{array}{l}\text { Aaron GJ, et } \\
\text { al. }(2011)[38]\end{array}$ & $\begin{array}{l}\text { Intervention group=270 } \\
\text { Control group=564 }\end{array}$ & 6 months & $\begin{array}{l}\text { Intervention Measurement: } \\
250 \mathrm{mls} \text { of pre-cooked maize and } \\
\text { soy with additional minerals and } \\
\text { vitamins served to children in } \\
\text { packs on each school day (5days/ } \\
\text { week) } \\
\text { Outcome measurement:Fasting } \\
\text { venous blood was taken at } \\
\text { baseline and end line and } \\
\text { hematological analysis done to } \\
\text { determine haemoglogin, serum } \\
\text { ferritin concentration }\end{array}$ & $\begin{array}{l}\text { Haemoglobin and serum } \\
\text { ferritin concentration } \\
\text { increased in both groups } \\
\text { but the changes did } \\
\text { not differ significantly } \\
\text { between the intervention } \\
\text { and control groups . } \\
\text { Odds ratio for anaemia } \\
\text { OR=0.69 } 95 \% \mathrm{Cl}(0.43- \\
1.11) \\
\text { Odds ratio for iron } \\
\text { deficiency OR=0.77, } 95 \% \\
\mathrm{Cl}(0.31-1.95)\end{array}$ & $\begin{array}{l}\text { *Negative } \\
\text { Intervention did } \\
\text { not significantly } \\
\text { improve } \\
\text { hemoglobin and } \\
\text { serum ferritin } \\
\text { levels }\end{array}$ & $\begin{array}{l}\quad \text { All children included in } \\
\text { the study at baseline had } \\
\text { haemoglobin } \geq 70 \mathrm{~g} / \mathrm{l}\end{array}$ \\
\hline $\begin{array}{l}\text { Muthayya S, } \\
\text { et al. (2012) } \\
\text { [42] } \\
\text { India }\end{array}$ & $\begin{array}{l}\mathrm{N}(\text { total) }=401 \text { at baseline ( } \\
\text { intervention group }=200 \text {, } \\
\text { control group }=201 \text { ) } \\
\mathrm{n}(\text { total) }=379 \text { at end line } \\
\text { (intervention group }=186 \text {, } \\
\text { control group }=193 \text { ) } \\
\text { children aged } 6-15 \text { years }\end{array}$ & 7 months & $\begin{array}{l}\text { Intervention measurement: Each } \\
\text { child received } 3 \text { standard sizes } \\
\text { of chapatis made from } 100 \mathrm{~g} \text { of } \\
\text { wheat flour with } 4 \text { different local } \\
\text { recipe for vegetable or lentil } \\
\text { dishes. Children were fed 6days/ } \\
\text { week except on holidays } \\
\quad \text { Outcome measurement: } \\
\quad \text { Hematological analysis was } \\
\text { done for haemoglobin, serum } \\
\text { ferritin, transferrin receptor, zinc } \\
\text { protoporphrin }\end{array}$ & $\begin{array}{l}\quad \text { Anaemia prevalence } \\
\text { reduced in treatment } \\
\text { group ( } 20.5 \text { to } 14 \% \\
p<0.001 \text { ) but increased } \\
\text { in control group (19.2 to } \\
24.4 \% ; p=0.05 \text { ) } \\
\quad \text { Prevalence of iron } \\
\text { deficiency decreased } \\
\text { in intervention group } \\
\text { (62.5\%- 20.5\%; } p<0.01) \\
\text { but did not change in } \\
\text { control group } \\
\quad \text { Iron deficiency anaemia } \\
\text { prevalence decreased } \\
\text { in intervention group } \\
\text { (17.7\%-8.6\%; } p<0.001 \text { ) but } \\
\text { there was no change in } \\
\text { control group }\end{array}$ & \begin{tabular}{|l|} 
*Positive \\
Intervention \\
significantly \\
reduced iron \\
deficiency and \\
iron deficiency \\
anaemia \\
\end{tabular} & $\begin{array}{l}\text { The study area is not } \\
\text { endemic for malaria and } \\
\text { presence of intestinal } \\
\text { parasites is low. } \\
\text { The wheat based meal } \\
\text { (chapatis) provided was } \\
\text { fortified with iron as NaFe } \\
\text { EDTA which is known to } \\
\text { protect iron from phytic } \\
\text { acid making iron more } \\
\text { bioavailable. } \\
\quad \text { Anemia was defined as } \\
\text { an Hb Conc. }<120 \mathrm{~g} / \mathrm{L} \text { in } \\
\text { children aged }>12 \mathrm{y} \text { and } \\
<115 \mathrm{~g} / \mathrm{L} \text { in children } \\
\text { aged } 5-11 \mathrm{y} \text {. } \\
\text { ID was defined as having } \\
\text { an SF }<15 \mathrm{mg} / \mathrm{L}\end{array}$ \\
\hline $\begin{array}{l}\text { Van } \\
\text { Stuijvenberg } \\
\text { ME, et al. } \\
\text { (2001) [39] }\end{array}$ & $\begin{array}{l}\mathrm{N}(\text { total)=139 } \\
\text { Intervention group=108 } \\
\text { Control group=31 } \\
\text { Children aged 6-11 years }\end{array}$ & 12 months & $\begin{array}{l}\text { Intervention measurement: } \\
\text { School pupils received } 3 \text { biscuits } \\
\text { weighing } 15 \text { g each within the } \\
\text { first two hours of school days. } \\
\text { Each child also received a cold } \\
\text { drink fortified with vitamin C } \\
\text { Outcome measurement: } \\
\text { Hematological analysis was done } \\
\text { to determine serum ferritin, } \\
\text { serum iron and total iron binding } \\
\text { capacity }\end{array}$ & $\begin{array}{l}\quad \text { Significant increase } \\
\text { in haemoglobin } \\
\text { concentration as well } \\
\text { as serum ferritin among } \\
\text { the intervention group } \\
\text { ( } p<0.0001 \text { and } p<0.005 \\
\text { respectively) }\end{array}$ & $\begin{array}{l}\quad \text { *Positive } \\
\quad \text { Intervention } \\
\text { resulted in } \\
\text { significant } \\
\text { improvement in } \\
\text { serum ferritin, } \\
\text { haemoglobin } \\
\text { and transferrin } \\
\text { saturation in } \\
\text { the intervention } \\
\text { group at } 12 \\
\text { months of follow } \\
\text { up }\end{array}$ & $\begin{array}{l}\text { Biscuits were fortified with } \\
\text { iron=5mg } \\
\quad \text { Children were also } \\
\text { dewormed with } 400 \mathrm{mg} \\
\text { albendazole at } 4 \text { monthly } \\
\text { interval } \\
\quad \text { Vitamin c rich drink } \\
\text { provided could enhance } \\
\text { iron absorption. } \\
\text { All indicators or iron status } \\
\text { were observed to have } \\
\text { declined after the summer } \\
\text { holidays }\end{array}$ \\
\hline $\begin{array}{l}\text { Lannotti LL, } \\
\text { et al. (2015) } \\
{[27]}\end{array}$ & $\begin{array}{l}\mathrm{N}(\text { total)=1167 } \\
\text { Mamba intervention } \\
\text { group=301(baseline), } \\
314(\text { endline) } \\
\text { Tablet Yo intervention } \\
\text { Group=347(baseline), } 332 \\
\text { (endline) } \\
\text { Control } \\
\text { group=288(baseline), } 251 \\
\text { (end line) } \\
\text { Children aged 3-13 years }\end{array}$ & 100 days & $\begin{array}{l}\text { Intervention Measurement: } \\
\text { Children in the Mamba group } \\
\text { received } 50 \mathrm{~g} \text { of the product and } \\
\text { the Tablet Yo group received } 42 \mathrm{~g} \\
\text { of the product once per day and } \\
\text { compliance was monitored } \\
\text { Outcome Measurement: } \\
\text { Biochemical, anthropometric and } \\
\text { bioelectrical impedance were } \\
\text { used to determine haemoglobin } \\
\text { concentration, nutritional } \\
\text { status and body composition } \\
\text { respectively }\end{array}$ & $\begin{array}{l}\text { Haemoglobin } \\
\text { concentration did not vary } \\
\text { significantly among groups } \\
\text { at end point ( } p=0.40 \text { ) } \\
\text { Anaemia prevalence did } \\
\text { not differ among groups } \\
\text { at end line ( } p=0.32 \text { ) } \\
\text { Mamba provision showed } \\
\text { reduced odds }(28 \%) \text { of } \\
\text { developing anaemia over } \\
\text { control ( OR=0.72, } 95 \% \mathrm{Cl}, \\
0.57-0.91)\end{array}$ & $\begin{array}{l}\text { *Negative } \\
\text { Intervention } \\
\text { has no impact } \\
\text { on mean } \\
\text { haemoglobin } \\
\text { concentration } \\
\text { and anaemia } \\
\text { prevalence with } \\
\text { only Mamba } \\
\text { showing } \\
\text { reduced odds } \\
\text { of developing } \\
\text { anaemia }\end{array}$ & $\begin{array}{l}\text { School pupils in the } \\
\text { intervention groups } \\
\text { were given take home } \\
\text { rations for } 10 \text { days during } \\
\text { vacation. } \\
\text { The Mamba group } \\
\text { received fortified food } \\
\text { One control school } \\
\text { reported children have } \\
\text { received iron supplements } \\
\text { from a community based } \\
\text { programme } \\
\text { Deworming was done for } \\
\text { both intervention groups } \\
\text { as well as control group. }\end{array}$ \\
\hline
\end{tabular}




\begin{tabular}{|c|c|c|c|c|c|c|}
\hline $\begin{array}{l}\text { Jacoby E, et } \\
\text { al. (1998) [47] }\end{array}$ & $\begin{array}{l}N(\text { Total })=116 \\
\text { Intervention group }=58 \\
\text { Control group }=58 \\
\text { School children aged } 5-10 \\
\text { years }\end{array}$ & 7 months & $\begin{array}{l}\text { Intervention measurement: daily } \\
\text { provision of breakfast consisting } \\
\text { of cake and milk like beverage } \\
\text { during school days } \\
\text { Outcome measurement: } \\
\text { Nonconsecutive } 24 \mathrm{Hr} \text { dietary }\end{array}$ & $\begin{array}{l}\text { Incidence of anaemia } \\
\text { reduced significantly in } \\
\text { the intervention group } \\
\text { from } 66 \% \text { to } 14 \% . \\
\text { Mean iron intake was } \\
\text { significantly higher } \\
(p<0.001) \text { in intervention } \\
\text { group }\end{array}$ & $\begin{array}{l}\text { *Positive } \\
\text { Intervention } \\
\text { reduced Anaemia } \\
\text { incidence and } \\
\text { increased iron } \\
\text { intake }\end{array}$ & $\begin{array}{l}\text { Data on dietary intakes } \\
\text { was reported for } 2 \text { months } \\
\text { of follow up. }\end{array}$ \\
\hline $\begin{array}{l}\text { Kazianga H, et } \\
\text { al (2009) [29] } \\
\text { Burkina Faso }\end{array}$ & $\begin{array}{l}N(\text { Total })=4140 \text { ( } 45 \text { schools) } \\
\text { Lunch group }=15 \text { schools } \\
\quad \text { Take home ration } \\
\text { group }=16 \text { schools } \\
\text { Control group }=14 \text { schools } \\
\text { School children aged } 6-15 \\
\text { years }\end{array}$ & 1 year & $\begin{array}{l}\text { Intervention measurement: } \\
\text { School based lunches were } \\
\text { provided every school day and } \\
\text { compliance monitored. 10kg of } \\
\text { cereal flour was provided as take } \\
\text { home rations every month } \\
\text { Outcome measurement: } \\
\text { Haemoglobin was measured and } \\
\text { difference in differences (DID) } \\
\text { specification is used to estimate } \\
\text { impact. }\end{array}$ & $\begin{array}{l}\text { There was no significant } \\
\text { impact of both school } \\
\text { based lunch and take } \\
\text { home rations on } \\
\text { haemoglobin levels. }\end{array}$ & $\begin{array}{l}\quad \text { *Negative } \\
\quad \text { Intervention } \\
\text { did not improve } \\
\text { haemoglobin } \\
\text { levels }\end{array}$ & $\begin{array}{l}\text { The take home rations } \\
\text { were given to only girls in } \\
\text { the selected schools. }\end{array}$ \\
\hline $\begin{array}{l}\text { Pinkaew S, et } \\
\text { al. (2013) [43] } \\
\text { Thailand }\end{array}$ & $\begin{array}{l}\mathrm{N}(\text { total })=203 \\
\text { Intervention group }=101 \\
\text { Control group }=102 \\
\text { School children aged 4-12 } \\
\text { years }\end{array}$ & 5 months & $\begin{array}{l}\text { Intervention measurement: } \\
\text { School lunch comprising rice with } \\
\text { chicken or fish and occasionally } \\
\text { with vegetables for } 5 \text { days/week. } \\
200 \mathrm{mls} \text { of milk is also provided } \\
5 \mathrm{~d} / \text { week } \\
\quad \text { Outcome measurement: } \\
\text { Biochemical analysis of } \\
\text { blood samples to determine } \\
\text { concentrations of Haemoglobin } \\
\text { and serum ferritin }\end{array}$ & $\begin{array}{l}\text { There was no significant } \\
\text { difference in change } \\
\text { in haemoglobin and } \\
\text { serum ferritin between } \\
\text { intervention and control. }\end{array}$ & $\begin{array}{l}\quad \text { *Negative } \\
\quad \text { Intervention } \\
\text { did not have a } \\
\text { significant impact } \\
\text { on haemoglobin } \\
\text { and serum } \\
\text { ferritin levels }\end{array}$ & $\begin{array}{l}\text { The rice used for the } \\
\text { intervention was triple } \\
\text { fortified with zinc, iron and } \\
\text { vitamin A. } \\
\text { All participants were not } \\
\text { iron deficient at baseline. } \\
\quad \text { Prior to the study, } \\
\text { all children were } \\
\text { receiving weekly iron } \\
\text { supplementation }\end{array}$ \\
\hline $\begin{array}{l}\text { Hulet JL, et al. } \\
\text { (2013) [41] }\end{array}$ & $\begin{array}{l}\text { N(total) }=360 \\
\text { Energy Group }=99 \\
\text { Milk Group }=105 \\
\text { Meat Group }=67 \\
\text { Control Group }=89\end{array}$ & 2 years & $\begin{array}{l}\text { Intervention measurement: } \\
\text { Intervention } 1: 185 \mathrm{~g} \text { of Githerie } \\
\text { with added oil served on each } \\
\text { school day except holidays } \\
\text { Intervention } 2: 185 \mathrm{~g} \text { of Githerie } \\
\text { with } 85 \mathrm{~g} \text { of minced meat served } \\
\text { each school day } \\
\text { Intervention } 3: 185 \mathrm{~g} \text { of Githerie } \\
\text { with } 250 \mathrm{ml} \text { of } \\
\quad \text { Outcome measurement: } \\
\text {-repeated24Hr dietary recall } \\
\text { were taken to estimate nutrient } \\
\text { intake. }\end{array}$ & $\begin{array}{l}\text { Dietary iron intake in the } \\
\text { energy group did not vary } \\
\text { significantly from the } \\
\text { control group. } \\
\text { The meat and milk groups } \\
\text { had significantly higher } \\
\text { iron intakes over baseline } \\
\text { levels and control }\end{array}$ & $\begin{array}{l}\quad \text { *Negative } \\
\quad \text { Energy } \\
\text { intervention } \\
\text { did not have an } \\
\text { impact on dietary } \\
\text { iron intake } \\
\text { *Positive } \\
\quad \text { Meat and milk } \\
\text { interventions had } \\
\text { a positive impact } \\
\text { on dietary iron } \\
\text { intakes }\end{array}$ & $\begin{array}{l}\text { Dietary iron intakes were } \\
\text { estimated as available } \\
\text { iron instead of total iron } \\
\text { intake. Availability was } \\
\text { calculated based on } 25 \% \\
\text { availability of haeme iron } \\
\text { for all people and that } 40 \% \\
\text { of iron from meat, fish and } \\
\text { poultry is haeme iron. }\end{array}$ \\
\hline $\begin{array}{l}\text { do Lien TK, et } \\
\text { al. (2009) [44] }\end{array}$ & $\begin{array}{l}\mathrm{N}(\text { total })=454 \\
\quad \text { Regular milk group }= \\
\quad \text { Fortified milk group= } \\
\text { Control group }= \\
\text { School children aged 7-8 } \\
\text { years }\end{array}$ & $\begin{array}{l}\quad 6 \text { months } \\
\text { (November } \\
\text { 2004-April } \\
\text { 2005) }\end{array}$ & $\begin{array}{l}\text { Intervention measurement: } \\
\text { Intervention 1: } 250 \mathrm{ml} \text { of regular } \\
\text { milk provided } 6 \text { days per week } \\
\text { and compliance monitored. } \\
\text { Intervention 2: } 250 \mathrm{ml} \text { of milk } \\
\text { fortified with mineral and } \\
\text { vitamins and inulin served in the } \\
\text { morning for } 6 \text { days per week } \\
\quad \text { Outcome measurement: } \\
\text { Biochemical analysis to assess } \\
\text { levels of haemoglobin, serum } \\
\text { ferritin. } \\
24 \text { Hr recalls conducted for } \\
\text { dietary intake }\end{array}$ & $\begin{array}{l}\text { Only fortified milk group } \\
\text { showed significant } \\
\text { increase in daily iron } \\
\text { intake over control } \\
\text { ( } p<0.01) \\
\quad \text { Anaemia reduced in } \\
\text { all groups and serum } \\
\text { ferritin levels increased in } \\
\text { bothgroups }\end{array}$ & $\begin{array}{l}\quad \text { *Positive } \\
\quad \text { Fortified milk } \\
\text { intervention } \\
\text { improved iron } \\
\text { intake } \\
\quad \text { Both } \\
\text { interventions } \\
\text { reduced anaemia }\end{array}$ & \\
\hline
\end{tabular}


Table 7: Summary Table of Included Studies: Observational Studies.

\begin{tabular}{|c|c|c|c|c|c|c|}
\hline $\begin{array}{l}\text { Study (year), } \\
\text { and Location }\end{array}$ & $\begin{array}{l}\text { Sample Size }(n), \\
\text { age of participants }\end{array}$ & $\begin{array}{l}\text { Duration of } \\
\text { intervention }\end{array}$ & $\begin{array}{l}\text { Measurement of exposure } \\
\text { and outcomes of interest }\end{array}$ & Summary of key findings & Direction of results & Remarks \\
\hline $\begin{array}{l}\text { Neervoort F, et } \\
\text { al. (2013) [28] } \\
\text { Kenya }\end{array}$ & $\begin{array}{l}\text { Intervention } \\
\text { group }=67 \\
\text { Control group }=81\end{array}$ & 1 year & $\begin{array}{l}\text { Exposure Measurement: } \\
\text { school based lunch provided } \\
\text { on each school day with } \\
\text { health education } \\
\quad \text { Outcome measurement: } \\
\text { Haemoglobin concentration } \\
\text { was measured and adjusted } \\
\text { for age and altitude }\end{array}$ & $\begin{array}{l}\text { Anaemia was } 19 \% \text { among } \\
\text { the intervention group and } \\
42 \% \text { anaemia prevalence } \\
\text { was recorded among the } \\
\text { control group (difference is } \\
\text { significant at } p=0.01 \text { ) }\end{array}$ & $\begin{array}{l}\text { *Positive Intervention } \\
\text { is associated with } \\
\text { lower anemia levels }\end{array}$ & $\begin{array}{l}\text { The following confounders } \\
\text { were adjusted for; family } \\
\text { size, age and education of } \\
\text { mother, adoption status, } \\
\text { amount of food consumed } \\
\text { at home. } \\
\text { All children were dewormed }\end{array}$ \\
\hline $\begin{array}{l}\text { Abizari AR, et al. } \\
\text { (2014) [52] } \\
\text { Ghana }\end{array}$ & $\begin{array}{l}\text { N(total)=383 } \\
\quad \text { SFP } \\
\text { participants=Non } \\
\text { SFP } \\
\text { participants=School } \\
\text { children aged 5-13 } \\
\text { years } \\
\\
\text { children aged 6-15 } \\
\text { years }\end{array}$ & & $\begin{array}{l}\quad \text { Exposure measurement: } \\
\text { School based lunch was } \\
\text { provided each school day } \\
\text { except on holidays } \\
\text { Outcome measurement: } \\
\text { 24Hr recalls, weighed food } \\
\text { records and biochemical } \\
\text { analysis to determine } \\
\text { concentrations of Hb, } \\
\text { serum ferritin and soluble } \\
\text { transferrin receptor }\end{array}$ & $\begin{array}{l}\quad \text { Mean probability of } \\
\text { adequacy of micronutrient } \\
\text { intake was significantly } \\
\text { higher among SFP } \\
\text { participants ( } 0.61 \text { vrs } 0.18 \text { ) } \\
\text { p<0.001 } \\
\text { SFP participants had } 6 \mathrm{~g} / \mathrm{I} \\
\text { higher } \mathrm{Hb} \text { concentration } \\
\text { ( } p<0.001 \text { ) and about } 10 \% \\
\text { points lower anaemia } \\
\text { prevalence ( } p=0.06 \text { ) } \\
\quad \text { Concentration of soluble } \\
\text { transferrin receptor was } \\
\text { lower in intervention group } \\
\text { ( } p=0.004 \text { ) } \\
\text { There was no significant } \\
\text { difference in iron and iron } \\
\text { deficiency anaemia. }\end{array}$ & $\begin{array}{l}\text { *Positive } \\
\text { SFP participants had a } \\
\text { higher Haemoglobin } \\
\text { concentration and } \\
\text { lower prevalence of } \\
\text { anaemia. } \\
\text { Iron intake was higher } \\
\text { SFP participants } \\
\text { *Negative } \\
\text { There is no significant } \\
\text { difference in Iron } \\
\text { deficiency and iron } \\
\text { deficiency anaemia } \\
\text { among SFP and Non } \\
\text { SFP participants }\end{array}$ & $\begin{array}{l}\text { Adjustment was done for } \\
\text { background differences. } \\
\quad \text { Study area is hyper } \\
\text { endermic for malaria } \\
\quad \text { Corn soy blend which } \\
\text { is given is multiple } \\
\text { micronutrient fortified and } \\
\text { orange was given twice a } \\
\text { week }\end{array}$ \\
\hline $\begin{array}{l}\text { Afridi F (2010) } \\
\text { [45] } \\
\text { India }\end{array}$ & $\begin{array}{c}\mathrm{N}(\text { total })=226 \\
\text { School meal } \\
\text { participants }=143 \\
\text { Non school meal } \\
\text { participants }=93 \\
\text { Children aged } \\
\text { children }\end{array}$ & & $\begin{array}{l}\text { Exposure measurement: } \\
\text { Provision of school lunch } \\
\text { each school day } \\
\text { Outcome measurement: } \\
24 \mathrm{Hr} \text { recalls for school day } \\
\text { and non school day }\end{array}$ & $\begin{array}{l}\text { Daily iron deficiency was } \\
\text { reduced by } 10 \% \text { associated } \\
\text { with school feeding during } \\
\text { school days } \\
\text { Increased iron intake } \\
\text { during school days by } 3.85 \\
\mathrm{mg}(\mathrm{p}<0.001)\end{array}$ & $\begin{array}{l}\quad \text { *Positive } \\
\quad \text { School feeding } \\
\text { during school days } \\
\text { is associated with } \\
\text { increased dietary iron } \\
\text { intake }\end{array}$ & \\
\hline $\begin{array}{l}\text { Walker SP, et al. } \\
\text { (1997) [48] } \\
\text { Jamaica }\end{array}$ & $\begin{array}{l}\mathrm{N}(\text { total })=147 \\
\text { School meal group } \\
=73 \\
\\
\text { Non school meal } \\
\text { group }=74 \\
\text { Children aged } 7-10 \\
\text { years }\end{array}$ & & $\begin{array}{l}\text { Exposure Measurement: } \\
\text { Children offered lunch in } \\
\text { school prepared by school } \\
\text { (paid for) during school days } \\
\text { Outcome Measurement: } \\
\text { Repeated } 24 \mathrm{Hr} \text { recalls of } \\
\text { dietary nutrient intake }\end{array}$ & $\begin{array}{l}\text { Dietary iron intake was } \\
\text { significantly higher in the } \\
\text { school meal group }(3.4 \mathrm{mg} \\
\pm 1.8 \text { vrs } 0.5 \mathrm{mg} \pm 0.9 \text { ) }\end{array}$ & $\begin{array}{l}\text { *Positive } \\
\text { School feeding was } \\
\text { associated with } \\
\text { increase dietary iron } \\
\text { intake }\end{array}$ & $\begin{array}{l}\text { School meals were relative } \\
\text { expensive }(\$ 6-10) \text { compared } \\
\text { to other cooked meals and } \\
\text { lunch items available from } \\
\text { shops and street vendors }\end{array}$ \\
\hline $\begin{array}{l}\text { Harding KB, et } \\
\text { al. (2012) [37] } \\
\text { Ghana }\end{array}$ & $\begin{array}{l}\mathrm{N}(\text { Total })=193 \\
\text { School feeding } \\
\text { participants }=104 \\
\text { School feeding Non } \\
\text { participants }=89 \\
\text { School children } \\
\text { aged } 2-5 \text { years }\end{array}$ & 7 months & $\begin{array}{l}\text { Exposure measurement: } \\
\text { SFP participants received } \\
\text { one meal at lunch for each } \\
\text { school day. Meals vary } \\
\text { Outcome measurement: } \\
24 \mathrm{Hr} \text { dietary recalls on two } \\
\text { non consecutive days. Blood } \\
\text { samples were analyzed for } \\
\text { haemoglobin levels }\end{array}$ & $\begin{array}{l}\text { SFP participants had } \\
\text { a higher intake of } \\
\text { iron compared to non } \\
\text { participants but after } \\
\text { controlling for confounders } \\
\text { SFP participants had } \\
\text { a reduced iron intake } \\
\text { compared to non } \\
\text { participants. } \\
\text { There was no significant } \\
\text { difference in haemoglobin } \\
\text { levels between the two } \\
\text { groups. }\end{array}$ & $\begin{array}{l}\text { *Negative } \\
\text { School feeding was } \\
\text { associated with } \\
\text { decreased dietary } \\
\text { iron intake and } \\
\text { haemoglobin levels } \\
\text { were not significantly } \\
\text { different between } \\
\text { participants and non } \\
\text { participants }\end{array}$ & $\begin{array}{l}\text { Foods used for the } \\
\text { feeding programme were } \\
\text { contributed by parents, } \\
\text { cooked and shared among } \\
\text { pupils. Foods were from } \\
\text { local sources and not } \\
\text { fortified. }\end{array}$ \\
\hline
\end{tabular}




\section{Dietary iron intake}

Four (4) trials $[40,41,44,47]$ were combined in the meta-analysis to determine the effect of school feeding programmes on dietary iron intake of primary school children. Two of these trials [40,41] provided three different types of feeding interventions using local recipes [44] provided fortified milk and regular milk as two separate feeding interventions whiles Jacoby ER, et al. [47] provided a beverage comprising cake and milk.

A total of 1,187 participants were included in the trials that contributed to determining the pool effect of the feeding programmes on dietary iron intake. Children who were in the experimental group, thus being fed in school were found to be getting more iron from their diets compared to those in the control group. Forest plots on dietary iron intake in figure 6 showed that School feeding resulted in a significantly increased $(\mathrm{p}<0.0001)$ dietary iron intake by $1.88 \mathrm{mg}(95 \%$ CI; 0.95-2.81) in participating children compared to non participants.

Heterogeneity was assessed to be considerable among the trials $\left(\mathrm{Tau}^{2}=1.63 ; \mathrm{Chi}^{2}=212.59 ; \mathrm{df}=8(\mathrm{p}<0.00001) ; \mathrm{I}^{2}=96 \%\right)$. To explore the sources of the heterogeneity, a sub group analysis using fortification status of meals was conducted and test of differences showed significant difference between fortified meals and non-fortified meals $\left(I^{2}=97.9 \% ; p<0.00001\right)$. Although both fortified meals and unfortified meals proved to significantly increase dietary iron intake of school meal participants, the fortified meal subgroup showed a higher margin of increase over their controls compared to the unfortified meal sub group (5.10 mg; 95\% CI, 4.21-5.99 vs $1.12 \mathrm{mg}$; 95\% CI, 0.41-1.84). See Appendix 5 for detailed sub group analysis.

The type of meals provided in school feeding programme is a source of difference in the its impact on dietary iron intake as demonstrated in a sub group analysis where a significantly higher dietary iron intake is observed among children provided with snacks ( $4.7 \mathrm{mg}$; $95 \% \mathrm{CI}$, 0.30-9.11, $\mathrm{p}=0.04$ ) whiles those who received a lunch made from local recipes did not record a significant increase in dietary iron intake over their controls.

School children who received meals of animal sources as well those who received meals from non-animal sources both had a significantly increased dietary iron intake compared to their controls although the non-animal source meals sub group recorded a relatively higher

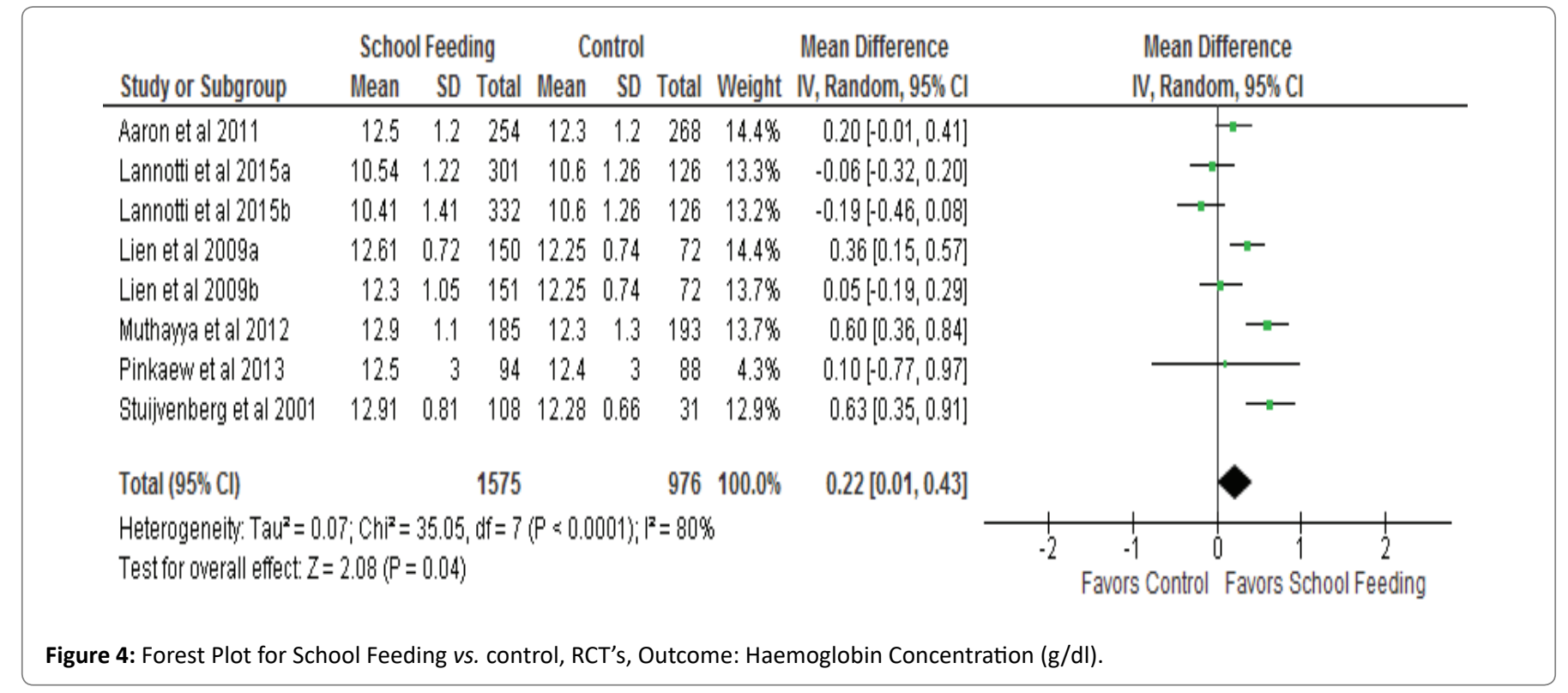

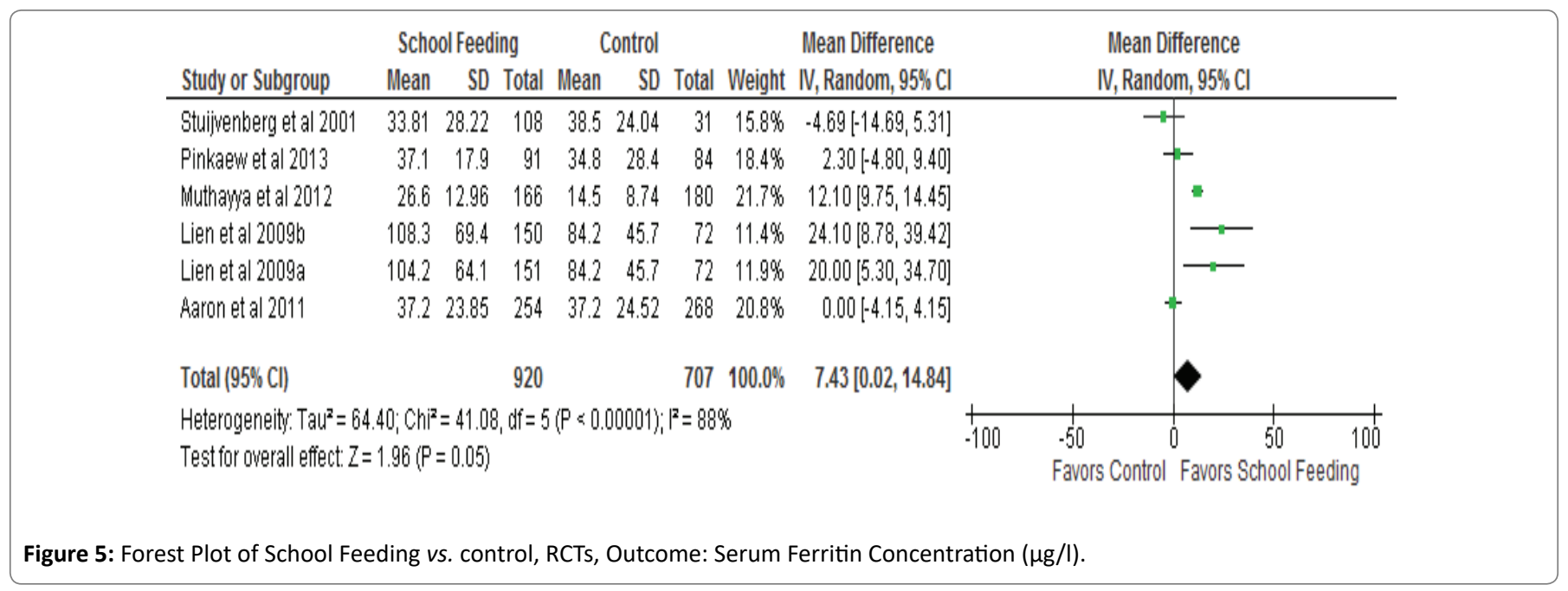




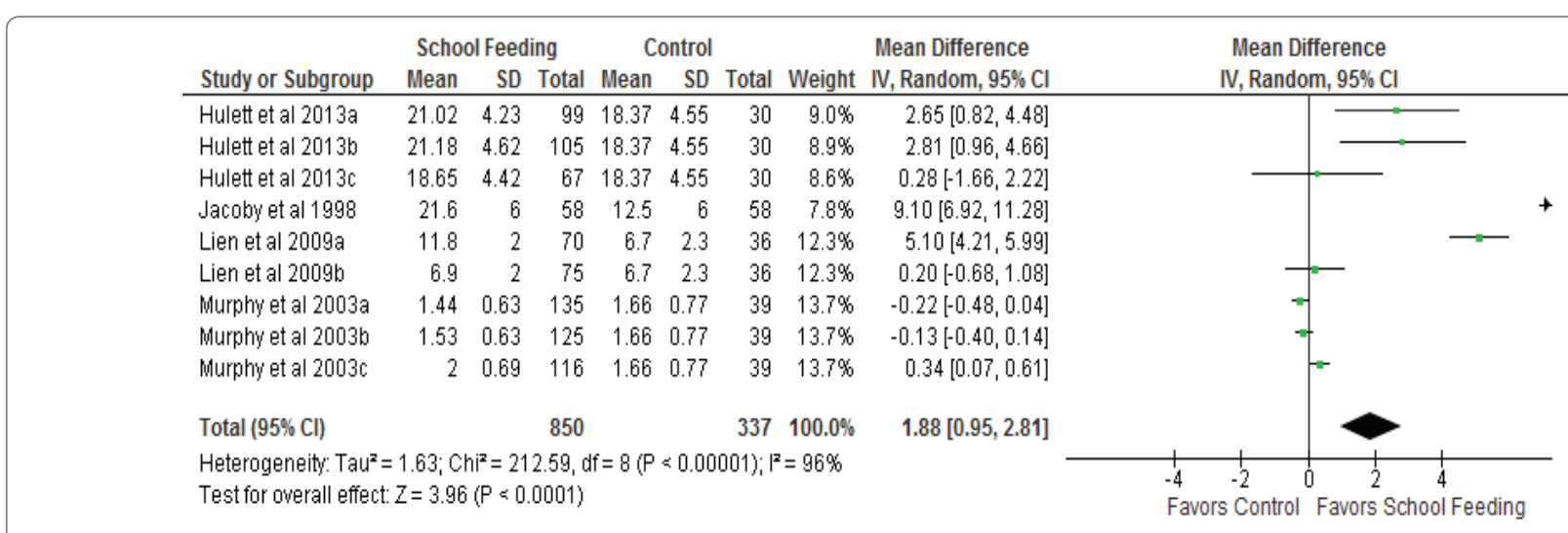

Figure 6: School Feeding vs. control, RCT's, Outcome: Dietary Iron Intake (mg).

impact on dietary iron intake (2.48 mg; 95\% CI, 1.15-3.82, vs $0.34 \mathrm{mg}$; 95\% CI, 0.07-0.61).

Jacoby ER, et al. [47] which is the only trial in this review conducted in Latin America which assessed programme impact on dietary iron intake showed a positive impact of school feeding on iron intake. Children who were provided feeding in school had a significantly increased $(\mathrm{p}<0.00001)$ iron intake by $9.10 \mathrm{mg}(95 \% \mathrm{CI} ; 6.92-11.28)$ over their controls. However a trial conducted in Asia [44] and two trials in Africa $[40,41]$ recorded marginal increases in dietary iron intake in favour of the experimental groups but the increases are not statistically significant ( $\mathrm{p}=0.28$ and $\mathrm{p}=0.20$ respectively).

\section{Discussion}

\section{Summary of evidence}

After screening 781 articles, a total of sixteen studies were included in this review of which nine trials were used in the meta-analysis. The studies were conducted in eleven developing countries across Africa, Asia and Latin America. The feeding interventions provided in the trials were either snacks or lunch made from local recipes.

The meta-analysis of six randomized controlled trials that included 2,551 primary school children showed an increase in haemoglobin concentrations of the children who were enrolled in the school feeding programme compared to non-participants although there was significant heterogeneity across studies. The increase in haemoglobin levels of programme participants over their controls was marginal $(0.22 \mathrm{~g} / \mathrm{dl}$ over an average feeding period of six months) and may be of limited clinical significance.

Programme impacts on haemoglobin were however higher when foods provided to children are fortified with iron. Fortification provided for only between $10 \%$ [38] to $50 \%$ [39] of the Recommended Daily Intake (RDI) for iron of the children who were provided with fortified foods. Therefore programme effects could have been even higher if fortification provided for a much higher proportion of the RDI of iron for children.

Also, when children were provided with a lunch made from local recipes instead of snacks, there is more impact on haemoglobin concentrations ( $0.53 \mathrm{~g} / \mathrm{dl}, 95 \% \mathrm{CI}, 0.20,0.8$ vs. $0.17 \mathrm{~g} / \mathrm{dl}$; $95 \% \mathrm{CI},-0.05$, $0.38)$.

This may be explained by the fact that such meals were probably more accepted and more likely to be eaten by children. They were also made from different varieties of local foods which contained iron and as such each individual food contributed to the iron content of the meals.

Contrary to the hypothesis of this review that severely anaemic children will benefit more from the intervention, school feeding proved more effective in improving the haemoglobin levels of children who were not severely anaemic before the intervention. This finding defies biological plausibility as iron bioavailability is expected to be up-regulated among individuals of low iron status [49]. This could therefore be explained by other factors within programme implementation such as low level of compliance [50]. Other factors that could account for this is the consumption of inhibitors of iron absorption among the severely anaemic sub group or other external factors such as malaria infection and worm infestations [20].

Serum ferritin concentration is a very useful measure of iron status and a very important indicator of iron deficiency anaemia [51]. This review has shown that school feeding programmes can have positive impacts on serum ferritin concentrations of primary school children. The meta-analysis of five trials including 1,627 children with a feeding intervention that lasted for an average of 7 months revealed an increase in serum ferritin concentrations of school feeding participants by $7.43 \mu \mathrm{g} / \mathrm{l}$ compared to controls. This increase is both statistically and clinically significant. If a similar trajectory were maintained following feeding for 14 months, children would have a serum ferritin concentration of about $15 \mu \mathrm{g} / \mathrm{l}$ due to school feeding alone which is above the threshold considered to be predictive for low iron storage and therefore iron deficiency anaemia [52].

The change in serum ferritin concentration associated with school feeding is more marked than the change in haemoglobin concentrations. This is probably because serum ferritin concentration is not affected by malaria, helminths and other micronutrient deficiencies as is the case for haemoglobin [20].

Food based approaches including dietary diversification; biofortification and fortification have been deemed to be most desirable and sustainable in preventing iron deficiency [53]. This was generally supported by the evidence from this review as school feeding programmes which provided diverse foods increased dietary iron intake of primary school children. This evidence is from a metaanalysis of four trials with multiple-arm interventions which included a total of 1,187 school children where programme participants had a dietary iron intake of $1.88 \mathrm{mg}$ more than non-participants.

Children who received fortified meals had a greater margin of difference in iron consumption compared to recipients of unfortified 
meals and controls for obvious reasons of intentional iron addition to the food and this probably accounts for the difference in programme impact on haemoglobin based on fortification status of meals.

This review also revealed that irrespective of the type of meals provided to school children whether made largely from animal sources or plant sources, school feeding can increase dietary iron intake (difference of $0.34 \mathrm{mg}$ and $2.48 \mathrm{mg}$ more than controls respectively). However, from this review, most of the iron consumed by children through the school feeding programmes are obtained from nonanimal sources which provide non haem iron which generally has a low bioavailability $(<10 \%)$ [54]. This therefore could have reduced the impact of the feeding interventions on haemoglobin and serum ferritin concentrations.

\section{Agreement and disagreements with other reviews}

There was no earlier review or meta-analysis of randomized controlled trials found on school feeding programmes and dietary iron intake and iron deficiency anaemia in developing countries. Instead, two Cochrane reviews of randomized controlled trials on impact of similar feeding interventions on haemoglobin concentrations were found.

One review [55] measured the impact of food supplementation at household level on improving physical and social health of socio economically disadvantaged children aged 3-5 years. The other review [56] analysed the effectiveness of school feeding but on improving the physical and psychosocial health of disadvantaged students. In both reviews, haemoglobin was assessed as a secondary outcome and only Kristjansson EA, et al., [55] conducted a meta-analysis on it using 5 randomized controlled trials which included 300 children.

The conclusion of this review that school feeding programmes can be effective in improving haemoglobin concentration of school children is similar to the findings of Kristjansson EA, et al. [55] where supplementary feeding resulted in an increased haemoglobin concentration and lowered anaemia levels in low income countries.

In contrast, the earlier review [56] which included very few studies that reported on biochemical outcomes, reported a mixed impact of school feeding on haemoglobin of children.

Another review article [57] was found which evaluated the impact of iron-fortified foods on haemoglobin concentration in children less than 10 years. The findings of Ramesh A, et al. [57] concur with the findings of this review that feeding with ironfortified foods is an effective strategy for reducing iron deficiency anaemia in children.

\section{Agreement and disagreements with other reviews}

This review included six observational studies which assessed the effects of school feeding on either one or more of the outcomes of interest. Two of them [36,37] evaluated programme impacts on haemoglobin concentrations and the results were mixed. The impact of school feeding on serum ferritin concentrations was reported by only one observational study [36] which found no significant differences between programme participants and controls.

All the observational studies included in this review that reported on dietary iron intake $[36,37,45,48]$ found school feeding programmes to significantly increase dietary iron intake of participants. This largely supports the findings from the meta-analysis of randomized controlled trials in this review of programme effectiveness in promoting dietary iron intake.

\section{Factors that may impact on effectiveness}

From this review school feeding programmes have shown small positive effects particularly on haemoglobin concentration. The interpretation of sub group analysis does indicate that effects could be higher with improvement in programme implementation. Notwithstanding this, there are a number of factors which could still have affected effectiveness.

Low haemoglobin concentration among school age children is not only due to iron deficiency but has multiple etiologies including malaria and other parasitic infections [58]. Most of the trials were done in Africa where malaria is endemic [59]. Only the study done by Muthayya S, et al. [42] in India described the study setting as not endemic for malaria and the presence of parasites being low. Deworming was done only in three studies $[27,38,39]$. The apparent high levels of parasitic infections among the children could have compromised programme effects on haemoglobin.

Evidence suggests that, in malaria endemic areas where asymptomatic malaria is protracted, iron absorption could be decreased by $40 \%$ [60]. This could further decrease the efficacy of feeding programmes to reduce iron deficiency anaemia.

Additionally, the absorption of dietary iron depends on other dietary factors which are either inhibitors (eg. Phytates and polyphenols) or enhancers (eg.. Vitamin C) [61]. The inclusion of any sources of either inhibitors or enhancers in the meals used for school feeding could have implications for programme effects on haemoglobin and serum ferritin concentration. Whereas the consumption of inhibitors is known to be widespread in developing countries [54], only two studies $[36,39]$ provided Vitamin $\mathrm{C}$ rich fruits and fortified drinks to enhance iron absorption.

Another factor that could affect programme impact is substitution; where the home diet may be reduced for children who are benefiting from school feeding. Though none of the studies in this review provided data on this, other studies have reported it among poor families $[62,63]$.

Considering that in this review even fortified school foods only provided a maximum of $50 \%$ of the RDI for iron of school pupils, it is essential that children are able to consume all of the day's ration of school meals in order to assure maximum dietary iron intake. However, daily compliance was only high (up to 80\%) in three trials $[38,39,42]$ and it was therefore not surprising that programme effects were high in these trials. Many studies did not report on compliance. However it does seem compliance could affect programme effects on outcomes.

\section{Conclusion}

In conclusion, this review has found school feeding programmes in developing countries to have small positive effects on dietary iron intake leading to a marginal positive impact on haemoglobin concentrations of primary school children. The impact on serum ferritin concentrations was significantly high and provides an indication of a high potential of feeding programmes to reduce iron deficiency anaemia among children in developing countries. However the quality of the evidence presented by this review is limited due to inherent risk of bias in the trials and the high level of heterogeneity.

The findings from this review imply that the magnitude of the impact of school feeding programmes on the reduction of iron deficiency anaemia will depend on the design, implementation and monitoring of the programme. 
This review provides evidence that has implications for practice such as the finding that iron deficiency anaemia may only be reduced among primary school children if school feeding programmes provide fortified foods. This suggests that reduction of iron deficiency anaemia may be unachievable by merely providing an additional meal through school feeding unless there is a deliberate addition of micronutrients (iron).

The use of local foods in school feeding programmes has the potential to promote food sovereignty and make school feeding programmes more sustainable [53]. Further evidence from this review suggest that school feeding using lunch made from local foods are more effective in reducing iron deficiency anaemia through adequate dietary iron consumption.

School feeding programmes have taken a paradigm shift from the traditionally food import driven programmes to Home-Grown School feeding where food is procured locally from small holder farmers to promote economic growth and sustainability [6]. From this review however, local foods still need to be fortified in order to achieve impacts on adequate micronutrient intake especially iron and to reduce iron deficiency anaemia therefore bio fortification could be explored.

Local communities in developing countries normally do not have the capacity to do large scale fortification hence the use of biofortification will serve the purpose of providing iron fortified foods even though the initial investment in research may be high [35].

The findings from this review equally have implications for further research. Very few primary research exist on the impact of school feeding on iron deficiency anaemia in developing countries as evidenced in the few studies included in this review despite many countries are implementing these programmes.

There is therefore the need for more randomized controlled trials which are of high methodological quality to be able to attribute causality and to be eligible to be used in a larger meta-analysis to confirm or otherwise reject the evidence produced by this review. In these studies, a lot more attention will need to be paid to the process of randomization, allocation concealment, blinding of outcome measurement especially when measuring dietary intake as well as attrition to improve quality.

Additionally, subsequent primary research will need to provide a breakdown of programme effects by age, sex and socioeconomic status in order for analysis to be accordingly stratified to cater for biological differences that exist due to these grouping. Other covariates such as children's percentage compliance to feeding and substitution effect should be adequately reported.

As finding from this review point to a high potential of school feeding programmes that use local foods to impact on reducing iron deficiency anaemia, there is need for larger studies that adopt the model of the home-grown school feeding as an intervention to evaluate impact on dietary iron intake and iron deficiency anaemia.

\section{Acknowledgements}

The authors thank Dr. Karen Pilkington for her great help in formulating the search strategy for literature and critically reviewing the manuscript. The authors also thank Dr. Amanda Adegboye who provided some useful perspectives during the performance of metaanalysis and was always available to provide further technical support.

Our appreciation also goes to Lora Lannotti who provided us with additional information from her study which was included in this review when we requested for it.

\section{Author Contribution}

The search strategy was developed and conducted by M.T.Y and L.V as well as the data extraction. All authors played very vital roles in writing and reviewing the article.

\section{Funding}

This research was not funded by any external parties or organization.

\section{Declaration of Interest}

The authors have no relevant interest to declare.

\section{References}

1. FAO, IFAD, WFP (2015) The State of Food Insecurity in the World 2015. Meeting the 2015 International Hunger Targets; Taking stock of uneven progress. Rome, Italy.

2. UNICEF, WHO, The World Bank (2015) Levels and Trends in Child Malnutrition.

3. Black RE, Allen LH, Bhutta ZA, Caulfield LE, de Onis M, et al. (2008) Maternal and Child Undernutrition: Global and Regional Exposures and Health Consequences. Lancet 371: 243-260.

4. Bundy D, Burbano C, Grosh M, Gelli A, Jukes M, et al. (2009) Rethinking School Feeding. Social Safety Nets, Child Development and the Educational Sector. The World Bank, Washington, USA.

5. UNICEF (2009) Tracking progress on child and maternal nutrition: A survival and development priority. New York, USA.

6. World Food Programme (2013) State of School Feeding Worldwide. World Food Programme. Rome, Italy.

7. Hall A, Hanh TT, Farley K, Quynh TP, Valdivia F (2007) An evaluation of the impact of a school nutrition programme in Vietnam. Public Health Nutr 10: 819-826.

8. Rahmani K, Djazayery A, Habibi MI, Heidari H, Dorosti-Motlagh AR, et al. (2011) Effects of daily milk supplementation on improving the physical and mental function as well as school performance among children: results from a school feeding program. J Res Med Sci 16: 469-476.

9. Neumann CG, Murphy SP, Gewa C, Grillenberger M, Bwibo NO (2007) Meat supplementation improves growth, cognitive, and behavioral outcomes in Kenyan children. J Nutr 137: 1119-1123.

10. Ruel MT, Menon P, Habicht JP, Loechl C, Bergeron G, et al. (2008) Agebased preventive targeting of food assistance and behaviour change and communication for reduction of childhood undernutrition in Haiti: a cluster randomised trial. Lancet 371: 588-595.

11. Lamis HJ, McDonnell E, Probart C (2011) School feeding programs in developing countries: impacts on children's health and educational outcomes. Nutr Rev 69: 83-98.

12. Kristjansson E, Francis DK, Liberato S, BenkhaltiJandu M, Welch V, et al. (2015) Food supplementation for improving the physical and psychosocial health of socio-economically disadvantaged children aged three months to five years. Cochrane Database Syst Rev 3: CD009924.

13. West KP, Caballero B, Black RE (2006) Nutrition. In: Merson M, Black $\mathrm{RE}$, Mills $A$ (eds) International public health: Diseases, programs, systems, and policies. $2^{\text {nd }}$ Edition, Jones and Bartlett Learning 187239.

14. World Health Organization (2008) Worldwide Prevalence of Anaemia 1993-2005. WHO Global Database on Anaemia. Geneva, Switzerland. 
15. UNICEF, UNU, WHO (2001) Iron Deficiency Anaemia. Assessment, Prevention and Control. A Guide for Programme Managers.

16. Lynch S (2007) Iron metabolism. In: Kraemer K, Zimmermann MB (eds) Nutritional Anemia. Sight and Life Press 60-76.

17. Hallberg L (2001) Perspectives on nutritional iron deficiency. Annu Rev Nutr 21: 1-21.

18. Gleason G, Scrimshaw NS (2007) An overview of the functional significance of iron deficiency. In Kraemer K, Zimmermann MB (eds) Nutritional Anemia. Sight and Life Press 45-57.

19. DeMaeyer EM, Adiels-Tegman M (1985) The prevalence of anaemia in the world. World Health Stat Q 38: 302-316.

20. McLean E, Cogswell M, Egli I, Woidyla D, De Benoist B (2009) Worldwide prevalence of anaemia, WHO Vitamin and Mineral Nutrition Information System, 1993-2005. Public Health Nutr 12 : 444-454.

21. Guesry GP (1998) The role of nutrition in brain development. Prev Med 27: 189-194.

22. FAO, WHO, UNU (2004) Human energy requirements. Report of a Joint FAO/WHO/UNU Expert Consultation, Rome, Italy.

23. WHO (2011) Haemoglobin concentrations for the diagnosis of anaemia and assessment of severity. Vitamin and Mineral Nutrition Information System. Geneva, Switzerland.

24. Kaptchuk TJ (2001) The double-blind, randomized, placebocontrolled trial: Gold standard or golden calf? J Clin Epidemiol 54: 541-549.

25. World Bank (2017) World Bank List of Economies 2014.

26. Edström J, Sabates-Wheeler R, Simwaka B (2008) A study of the take-home food rations for orphans and vulnerable children in communities affected by AIDS in Malawi. UNICEF ESARO, Nairobi, Kenya.

27. Lannotti LL, Henretty NM, Delnatus JR, Previl W, Stehl T, et al. (2015) Ready-to-Use Supplementary Food Increases Fat Mass and BMI in Haitian School-Aged Children. J Nutr 145: 813-822.

28. Neervoort F, Von Rosenstiel I, Bongers K, Demetriades M, Shacola $M$, et al. (2013) Effect of a school feeding programme on nutritional status and anaemia in an urban slum: a preliminary evaluation in Kenya. J Trop Pediatr 59: 165-174.

29. Kazianga $H$, de Walque $D$, Alderman $H$ (2009) Educational and Health Impacts of Two School Feeding Schemes: Evidence from a randomized trial in Burkina Faso. Policy research working papers 4976.

30. Higgins JPT, Green S (2011) Cochrane Handbook for Systematic Reviews of Interventions. John Wiley and Sons.

31. Hozo SP, Djulbegovic B, Hozo I (2005) Estimating the mean and variance from the median, range, and the size of a sample. BMC Med Res Method 5.

32. Higgins JM, Thompson SG, Deeks JJ, Altman DJ (2003) Measuring Inconsistency in meta-analysis. BMJ 327: 557-560.

33. Egger M, Smith GD, Schneider M, Minder C (1997) Bias in metaanalysis detected by a simple, graphical test. BMJ 315: 629-634.

34. Fomon $S$ (2001) Infant feeding in the $20^{\text {th }}$ century: formula and beikost. J Nutr 131: 409S-420S.

35. Gibson RS, Perlas L, Hotz C (2006) Improving the bioavailability of nutrients in plant foods at the household level. Proc Nutr Soc 65: 160-168.
36. Abizari AR, Buxton C, Kwara L, Mensah-Homiah J, Armar-Klemesu M et al. (2014) School Feeding Contributes to Micronutrient Adequacy of Ghanaian Schoolchildren. Br J Nutr 112: 1019-1033.

37. Harding KB, Marquis GS, Colecraft EK, Lartey A, Sakyi-Dawson O (2012) Participation in Communal Day Care Centre Feeding Programs is associated with higher diet quantity but not quality among rural Ghanaian children. African J Food Agri Nutr Dev 12: 1-20.

38. Aaron GJ, Kariger P, Aliyu R, Flach M, lya D, et al. (2011) A Multimicronutrient Beverage Enhances the Vitamin A and Zinc Status of Nigerian Primary School children. J Nutr 141: 1565-1572.

39. van Stuijvenberg ME, Dhansay MA, Smuts CM, Lombard CJ, Jogessar VB, et al. (2001) Long-term evaluation of a micronutrient-fortified biscuit used for addressing micronutrient deficiencies in primary school children. Public Health Nutr 4: 1201-1209.

40. Murphy SP, Gewa S, Liang LJ, Grillenberger M, Bwiboz NO, et al. (2003) School Snacks Containing Animal Source Foods Improve Dietary Quality for Children in Rural Kenya. J Nutr 133: 3950S-3956S.

41. Hulett JL, Weiss RE, Bwibo NO, Galal OM, Drorbaugh N, et al. (2013) Animal source foods have a positive impact on the primary school test scores of Kenyan schoolchildren in a cluster-randomised, controlled feeding intervention trial. Br J Nutr 111: 875-886.

42. Muthayya S, Thankachan P, Hirve S, Amalrajan V, Thomas $T$, et al. (2012) Iron Fortification of Whole Wheat Flour Reduces Iron Deficiency and Iron Deficiency Anemia and Increases Body Iron Stores in Indian School-Aged Children. J Nutr 142: 1997-2003.

43. Pinkaew S, Winichagoon P, Hurrell RF, Wegmuller R (2013) Extruded Rice Grains Fortified with Zinc, Iron and Vitamin A Increase Zinc Status of Thai School Children When Incorporated into a School Lunch Program. J Nutr 143: 362-368.

44. do Lien TK, Nhung BT, Khan NC, Hop LT, Nga NT, et al. (2009) Impact of milk consumption on performance and health of primary school children in rural Vietnam. Asia Pac J Clin Nutr 18 : 326-334

45. Afridi F (2010) Child Welfare Programs and Child Nutrition: Evidence from a Mandated School Meal Program in India. J Dev Econ 92: 152165.

46. Buttenheim A, Alderman H, Friedman J (2011) Impact Evaluation of School Feeding Programmes in Lao People's Democratic Republic. J Dev Effect 3: 520-542.

47. Jacoby ER, Cueto S, Pollitt E (1998) When science and politics listen to each other: good prospects from a new school breakfast program in Peru. Am J Clin Nutr 67: 795S-797S.

48. Walker SP, Powell CA, Hutchinson SE, Chang SM, GranthamMcGregor SM (1997) Schoolchildren's diets and participation in school feeding programmes in Jamaica. Public Health Nutr I: 43-49.

49. Bezwoda WR, Bothwell TH, Torrance JD, MacPhail AP, Charlton RW, et al. (1979) The Relationship between Marrow Iron Stores, Plasma Ferritin Concentrations and Iron Absorption. Scand J Haematol 22 113-120.

50. Tisdall FF, Robertson EC, Drake TG, Jackson SH, Fowler HM, et al. (1951) The Canadian Red Cross School Meals Study. Can Med Assoc J 64: 477-489.

51. Mei Z, Cogswell ME, Parvanta I, Lynch S, Beard JL, et al. (2005) Hemoglobin and ferritin are currently the most efficient indicators of population response to iron interventions: an analysis of nine randomized controlled trials. J Nutr 135: 1974-1980.

52. Abizari AR, Moretti D, Zimmermann MB, Armar-Klemesu M Brouwer ID (2012) Whole Cowpea Meal Fortified with NaFeEDTA Reduces Iron Deficiency among Ghanaian School Children in a Malaria Endemic Area. J Nutr 142: 1836-1842. 
53. Zimmermann MB, Hurrell RF (2007) Nutritional iron deficiency. Lancet 370: 511-520.

54. Kristjansson EA, Francis DK, Liberato $\mathrm{S}$, Benkhaltijandu M, Welch $\mathrm{V}$, et al. (2015) Food supplementation for improving the physical and psychosocial health of socio-economically disadvantaged children aged three months to five years. Cochrane Database Syst Rev 3 : CD009924.

55. Kristjansson EA, Robinson V, Petticrew M, MacDonald B, Krasevec J, et al. (2007) School feeding for improving the physical and psychosocial health of disadvantaged elementary school children. Cochrane Database Syst Rev 1: CD004676.

56. Ramesh A, Rao MV, Nair KM (2013) Impact of iron-fortified foods on $\mathrm{Hb}$ concentration in children (10 years): a systematic review and meta-analysis of randomized controlled trials. Public Health Nutr 17: 579-586.
57. World Health Organization (2015)|World malaria report 2015. World Health Organization.

58. Hoffbrand V, Moss P, Pettit J (2006) Essential haematology. $5^{\text {th }}$ Edition, Wiley 1-392.

59. Cercamondi Cl, Egli IM, Ahouandjinou E, Dossa R, Zeder C, et al. (2010) Afebrile Plasmodium Falciparum Parasitemia Decreases Absorption of Fortification Iron but Does not Affect Systemic Iron Utilization: A Double Stable-Isotope Study in Young Beninese Women. Am J Clin Nutr 92: 1385-1392.

60. WHO, FAO (2006) Guidelines on food fortification with micronutrients. Geneva, Switzerland.

61. Jacoby E, Cueto S, Pollitt E (1996) Benefits of a school breakfast among Andean children in Huaraz, Peru. Food Nutr Bull 17: 1-11.

62. Agarwal DK, Agarwal KN, Upadhyay SK (1989) Effect of Mid-Day Meal Programme on Physical Growth and Mental Function. Indian J Med Res 90: 163-174. 